\title{
The utilization of humanized mouse models for the study of human retroviral infections
}

\author{
Rachel Van Duyne ${ }^{\dagger 1}$, Caitlin Pedati ${ }^{\dagger 2}$, Irene Guendel ${ }^{2}$, Lawrence Carpio², \\ Kylene Kehn-Hall ${ }^{2}$, Mohammed Saifuddin ${ }^{3}$ and Fatah Kashanchi ${ }^{* 2}$
}

\begin{abstract}
Address: ${ }^{1}$ Microbiology, Immunology, and Tropical Medicine Program, The George Washington University School of Medicine, Washington, DC 20037, USA, ${ }^{2}$ Department of Microbiology, Immunology, and Tropical Medicine, The George Washington University School of Medicine, Washington, DC 20037, USA and 3CONRAD, Eastern Virginia Medical School, 1911 Fort Myer Drive, Suite 900, Arlington, VA 22209, USA

Email: Rachel Van Duyne - bcmrvv@gwumc.edu; Caitlin Pedati - bcmcsp@gwumc.edu; Irene Guendel - mtmixg@gwumc.edu; Lawrence Carpio - lawrence.carpio@gmail.com; Kylene Kehn-Hall - bcmkwk@gwumc.edu; Mohammed Saifuddin - msaifuddin@conrad.org; Fatah Kashanchi* - bcmfxk@gwumc.edu

* Corresponding author †Equal contributors
\end{abstract}

Published: 12 August 2009

Retrovirology 2009, 6:76 doi:10.1/86/1742-4690-6-76
Received: 24 March 2009

Accepted: 12 August 2009

This article is available from: http://www.retrovirology.com/content/6/I/76

(C) 2009 Van Duyne et al; licensee BioMed Central Ltd.

This is an Open Access article distributed under the terms of the Creative Commons Attribution License (http://creativecommons.org/licenses/by/2.0), which permits unrestricted use, distribution, and reproduction in any medium, provided the original work is properly cited.

\begin{abstract}
The development of novel techniques and systems to study human infectious diseases in both an in vitro and in vivo settings is always in high demand. Ideally, small animal models are the most efficient method of studying human afflictions. This is especially evident in the study of the human retroviruses, HIV-I and HTLV-I, in that current simian animal models, though robust, are often expensive and difficult to maintain. Over the past two decades, the construction of humanized animal models through the transplantation and engraftment of human tissues or progenitor cells into immunocompromised mouse strains has allowed for the development of a reconstituted human tissue scaffold in a small animal system. The utilization of small animal models for retroviral studies required expansion of the early CB-I7 scid/scid mouse resulting in animals demonstrating improved engraftment efficiency and infectivity. The implantation of uneducated human immune cells and associated tissue provided the basis for the SCID-hu Thy/Liv and hu-PBL-SCID models. Engraftment efficiency of these tissues was further improved through the integration of the nonobese diabetic (NOD) mutation leading to the creation of NODSCID, NOD/Shi-scid IL2 $\mathrm{rr}^{-1-}$, and NOD/SCID $\beta 2$-microglobulinnull animals. Further efforts at minimizing the response of the innate murine immune system produced the Rag2 ${ }^{-1-} \gamma_{c}{ }^{-/}$model which marked an important advancement in the use of human CD34+ hematopoietic stem cells. Together, these animal models have revolutionized the investigation of retroviral infections in vivo.
\end{abstract}

\section{HIV-I Pathogenesis}

The HIV-1 virus is the etiologic agent of AIDS (Acquired Immunodeficiency Syndrome) and a life-long infection results in the destruction of lymphocytes, rendering the host immunocompromised $[1,2]$. The development of AIDS in HIV-1 infected individuals has been defined as a result of a combination of two different types of infections characterized by an acute phase where the virus can rapidly deplete CD4+ T cells and a chronic phase where the damaged immune system gradually loses all functionality [3-5]. Though the primary target is CD4+ T cells, the HIV1 virus can also infect both monocytes/macrophages and dendritic cells (DCs), however, cellular tropism of the virus is determined by the expression of the cell surface 
receptor CD4 and the coreceptors CCR5 and CXCR4. Genetic variability in the expression of these cell surface markers can lead to differences in susceptibility by socalled R5 viruses which recognize CCR5, R5X4 viruses which recognize both CCR5 and CXCR4, and X4 viruses which recognize only CXCR4 [6-8]. The activity and longevity of the integrated HIV-1 provirus can be directly correlated to both the activation state as well as the survival of the cell. This phenomenon results in dramatically different viral pathogenicity in activated as compared to both resting and quiescent CD4+ T cells $[3,9,10]$. Primary HIV1 infection is asymptomatic during the first two weeks after exposure to the virus; however, acute HIV-1 infection is evident by a dramatic burst of viral replication correlating with infection of activated T cells. This initial infection and high viral replication efficiency result in a high titer of virus present in the plasma of infected individuals that gradually drops off as the infection induces a cytopathic effect on the T cells after approximately nine weeks post infection. This acute viremia is also correlated with an active host immune response against the infection in the form of cytotoxic T lymphocyte (CTLs) CD8+ cells that recognize HIV-1 infected cells and induce cell death [1113]. This CD8+ CTL response correlates with the production of HIV-1 neutralizing antibodies or seroconversion of the patient. An additional population of CD4+ T cells can be classified as resting or permissive where cellular replication is restricted at several different steps; however, there exists enough stimulatory signals to push the cell into the $\mathrm{G}_{1}$ phase of the cell cycle. In HIV-1 positive individuals, the resting CD4+ T cells contain HIV-1 DNA in a linear form (in the cytoplasm of the cell) representing an inducible viral population that can be properly integrated upon the correct stimulation. Despite the cytoplasmic localization of the majority of viral DNA, low levels of integrated HIV-1 can be isolated from a small subset of the resting $\mathrm{T}$-cell population which is most likely due to infected, activated CD4+ T cells that have reverted back to a resting state, a commonly seen phenomenon important for the establishment of immunologic memory [14,15]. Similarly, infected quiescent or refractory CD4+ T cells also exhibit viral replication restrictions where the provirus exists integrated in the genome in a silent or latent state [15-18]. The establishment of transcriptionally silent provirus does not occur only in this subset of $\mathrm{T}$ cells; indeed, actively dividing $\mathrm{T}$ cells can contain viral reservoirs as latency can be an intrinsic property of the virus [19]. It is assumed that the provirus is established in these cells during normal progression through the cell cycle and in response to the infection to avoid cytopathicity and immune clearance. After the reverse transcription step has been completed, the cell establishes itself at $\mathrm{G}_{0}$, blocking further progression $[3,15,18]$. This establishment of a latent population of cells containing integrated provirus signifies the clinical latency period of infection, where the maintenance of $\mathrm{T}$ cell homeostasis and low viral loads occur until the terminal stages of infection and progression to disease $[15,18,20,21]$.

The fidelity of the HIV-1 RT as well as the rapid viral replication rate contribute to the diversity of the viral progeny. In an active infection $10^{9}-10^{10}$ virions are produced per day, and during each viral replication cycle there is a mutation rate of approximately $3 \times 10^{-5}$ nucleotides due primarily to a "slippery" RT $[22,23]$. The introduction of multiple point mutations in the viral genome results in many different strains of virus within an infected individual, as well as the possibility of one cell being infected by different strains, leading to recombination events. Additionally, the genomic variability leads to differences in protein sequence and structure, resulting in difficulties in developing antiretroviral drugs against the viral integrase, protease, and RT. This results in the appearance of drugresistant HIV-1 variants in the face of antiretroviral therapies. This necessitates a cocktail of antiretroviral drugs known as HAART (highly active antiretroviral therapy) as the primary treatment for HIV-1 infected individuals who need to be constantly evaluated for treatment effectiveness against the viral strains present [24-29].

In addition to the primary infection of susceptible populations of CD4+ T cells and monocytes/macrophages DCs can also support the integration of proviral DNA $[3,30]$. Tissue macrophages are infected primarily through the CCR5 coreceptor, and individuals that lack CCR5 are highly resistant to infection, irrespective of CD4+ T cell infection [31-34]. Infection of tissue macrophages assists in the progressive infection of CD4+ T cells due to interactions of the HIV-1 viral protein Nef through stimulation of the CD40 receptor and activation of the NF- $\kappa \mathrm{B}$ pathway [35]. Subsequent secreted proteins increase the expression of stimulatory receptors on B cells, which then interact with corresponding ligands on CD4+ T cells, allowing for either viral entry and the expression of viral proteins or the productive infection of susceptible CD4+ T cells [35].

The loss of CD4+ T cells in HIV-1 infected individuals leaves the host susceptible to opportunistic infections, many of which are normally blocked through mucosal barriers and innate immunity. The infection of the gutassociated lymphoid tissue (GALT) of the HIV-1 infected gastrointestinal (GI) tract and the pathogenesis surrounding this manifestation are termed HIV enteropathy [3640]. Viral replication within the GALT tissue is compartmentalized with different anatomical areas of the gut exhibiting higher levels of infected cells in one site than others, i.e. esophagus, stomach, duodenum and colorectum [41]. This is due largely to the wide range of distribution and composition of lymphoid tissues in the gut, including Peyer's patches in the small intestine, lymphoid 
follicles in the large intestine and rectum, and a majority of CD8+ T cells in the intraepithelium of the small intestine [41]. This situation allows for the selection of various HIV-1 susceptible cell types within different areas of the GALT. The HIV-1 induced local activation and inflammation of the GI immune system result in the recruitment and infiltration of CD4+ T cells and CD8+ T cells to the mucosal tissues [38]. Indeed in HIV-1 infected individuals, there is an increase in the proinflammatory lymphocyte response as well as an absence of CCR5+ CD 4+ T cells within the GI tract during the acute stage of infection. Rapid elimination of CD4+T cells associated with structural damage of the gut is thought to cause leakage of bacterial pathogens/products into the blood stream resulting in hyperimmune activation, the hallmark of immunopathogenesis of HIV disease [42]. CD4+ T cells in the GI tract are 10-fold more likely to be infected by HIV-1 than those in the peripheral blood; however, the predominance of HIV-1 specific CD8+ T cells in the GI tract is comparable to the CD4+ levels observed in peripheral blood [43-45]. The induction of a mucosal humoral immune response through activation of a functional HIV-1 specific T-cell response may help to control viral replication and inhibit viral spread within the GI tract.

\section{Comparison of animal models for the study of retroviral infection}

The identification of HIV-1 as the causative agent of AIDS was followed only a year later by the recruitment of chimpanzees for the purpose of in vivo research into the disease and its associated pathogenesis, treatment, and prevention [46]. Chimpanzees represented a logical and ideal starting animal model because of their documented DNA homology with humans; the two species share between 97 and $98 \%$ of their genomes. However, on a practical level, this animal was also recognized as an endangered species in certain areas; and despite genetic similarities, there are also many differences that affect immune responses and clinical manifestations of infection with human viruses, such as HIV-1 [46,47].

Early experiments in the 1980s utilizing chimpanzees demonstrated a series of important insights into HIV-1 infection, including the ability to be transmitted through blood and vaginal secretions [46]. These investigations were able to establish an HIV-1 infection of HIV-1 in chimpanzees with successful viral entry, expression, subsequent productive viral replication and even IgG immune response mimicking human conditions. However, important differences in cell-mediated immune responses began to emerge, especially in the case of the studies by Zarling et al. where they observed that CTLs that developed in humans and played an important role in pathogenesis were not present in chimpanzees [48]. Chimpanzees were also not developing the same markers of disease as humans, such as increases in $\beta 2$ microglobu- lin, TNF- $\alpha$, and IL- 6 . Attention shifted to other options including the use of HIV-2 and Simian Immunodeficiency Virus (SIV) as infection models. HIV-2 proved successful in infecting cynomologus macaques while SIV was useful for investigating clinical progression, particularly in juvenile macaques, of immunodeficiency as it compared to the disease in humans [49-51]. However both of these systems have limitations including differences in the natural progression of disease as well as challenges in accurately targeting therapeutic interventions, in addition to the high cost of animals. The combination of the HIV-1 envelope gene with the naturally occurring lentivirus in primates, SIV, produced a chimeric virus known as SHIV [52]. SHIV models in rhesus and pigtail macaques have provided some success as surrogates for HIV-1 infection in humans. However, a major difference remains, the development of AIDS, occurring in this primate model within about 2-6 months period as opposed to the often longer latency observed in humans. Therefore this SHIV model is considered a useful representation of acute infection that progresses rapidly but is not necessarily an accurate reflection of the insidious HIV-1 infection and disease course. Some SIV strains such as SIVmac251 do in fact demonstrate more of a chronic infection and have found some success in efforts aimed at vaccine development, though some differences with HIV-1 still exist with regard to pathogenesis. Recent data show that chimpanzees infected with SIVcpz are able to develop an immunopathology similar to human AIDS [53] suggesting that this model holds further utility.

Despite the usefulness of non-human primates for investigations of human retroviruses, the difficulties encountered with respect to ethical, financial, and immunological challenges have led quickly to the exploration of smaller animal models (Table 1). One such model utilizing feline immunodeficiency virus (FIV) infection has provided limited insight for comparison to human disease, though this model has shown some promise vaccine development efforts and also in relevance for to human neuropathy related to HIV infection $[54,55]$. Rats have also been utilized for pharmacological research as well as HIV-1 associated dementia [47]. Transgenic animals, both rat and mouse, have also demonstrated value especially for investigations concerning entry or the effects of viral integration on specific tissues [47]. However, transgenic animals are limited in the ability to study therapeutics or vaccines since viral replication and proliferation are not fully achieved in these models [47]. In particular, the major impairment in the transgenic rat models occurs at the level of viral gene expression and maturation of viral particles $[56,57]$. While it is possible to infect these animal models with HIV-1, problems arise in the later stages of the viral life cycle resulting in an inability to sustain viral production. Although these transgenic models could mimic the early events in viral 
Table I: Comparison of Animal models for the Investigation of Retroviral Infections

\begin{tabular}{|c|c|c|c|c|}
\hline Type of Model & Viral Infection & Method of Infection & Advantage & Disadvantage \\
\hline \multirow{4}{*}{$\begin{array}{l}\text { Non-Human Primates } \\
\text { (chimpanzees, rhesus, pigtail, } \\
\text { cynomologus ymacaques, } \\
\text { etc.) }\end{array}$} & $\cdot$ HIV-I & $\cdot \mathrm{IV}$ & $\begin{array}{l}\text { - Useful for vaccine and } \\
\text { therapeutic studies }\end{array}$ & $\begin{array}{l}\text { - SIV/SHIV are surrogates for HIV } \\
\text { infection }\end{array}$ \\
\hline & $\cdot \mathrm{HIV}-2$ & - Vaginal & $\begin{array}{l}\text { - Genetic similarities between } \\
\text { species }\end{array}$ & $\begin{array}{l}\text { - Differences in time course of } \\
\text { disease }\end{array}$ \\
\hline & $\cdot \operatorname{SIV}$ & - Rectal & & $\begin{array}{l}\text { - Differences in molecular and } \\
\text { cellular markers }\end{array}$ \\
\hline & • SHIV & & & $\begin{array}{l}\text { - Significant cost and ethical } \\
\text { concerns }\end{array}$ \\
\hline \multirow[t]{3}{*}{ Feline } & • FIV & $\bullet \mathrm{IV}$ & $\begin{array}{l}\text { - Insight into neurological AIDS } \\
\text { complications }\end{array}$ & - Strictly surrogate model \\
\hline & & & $\begin{array}{l}\text { - Pharmacological and vaccine } \\
\text { studies }\end{array}$ & \\
\hline & & - Rectal & & \\
\hline \multirow[t]{4}{*}{ Transgenic Mice/Rats } & $\cdot$ HIV-I & $\cdot$ IV & - Cost and accessibility & $\begin{array}{l}\text { - Lack of viral replication and } \\
\text { proliferation }\end{array}$ \\
\hline & & & - Manipulation of genome & \\
\hline & - None & $\begin{array}{l}\text { - Transgenic insertion of } \\
\text { HIV genes }\end{array}$ & - Fusion and entry & \\
\hline & & & $\begin{array}{l}\text { - Effect of virus on different } \\
\text { tissues }\end{array}$ & \\
\hline \multirow[t]{6}{*}{ Humanized Mice } & $\cdot$ HIV-I & $\cdot$ IV & - Cost and accessibility & $\begin{array}{l}\text { - Further characterization of } \\
\text { pathogenesis and continued } \\
\text { evolution of model expected }\end{array}$ \\
\hline & & $\bullet \mathrm{IP}$ & - Manipulation of genome & \\
\hline & & - Vaginal & $\begin{array}{l}\text { - Creation of human immune } \\
\text { system scaffold for } \\
\text { proliferating virus }\end{array}$ & \\
\hline & & & - Mucosal infections & \\
\hline & & - Rectal & $\begin{array}{l}\text { - Vaccine and therapeutics at } \\
\text { varying stages of viral life cycle }\end{array}$ & \\
\hline & & - Thy/Liv & & \\
\hline
\end{tabular}

replication, a significant block is encountered at the point of integration, ultimately creating a limited picture of productive systemic infection [58]. Recent developments have shown that murine models (e.g. humanized mice) have become increasingly desirable for retroviral infection studies. Mice represent an ideal research option not only for their relatively low cost and ease of access, but also because of the ever increasing ability to manipulate the mouse genome in order to more accurately reflect what is happening in human infection at both the molecular and clinical levels [47]. These murine models are continuing to evolve, and new approaches are being developed for establishing an accurate picture of human retroviral infection and for allowing relevant investigation of therapeutic and preventive options.

\section{A brief history of humanized mouse models} The first humanized mouse model to be developed was in 1983 by Bosma et al. through the discovery of the scid mutation in CB-17 scid/scid (SCID) mice [59]. These mice contained an autosomal recessive mutation in the prkdc (protein kinase, DNA activated, catalytic polypeptide) gene resulting in a deficiency in mature $\mathrm{T}$ and $\mathrm{B}$ lymphocytes. This mutation resulted in the ability of these mice to accept foreign tissues, therefore allowing the engraftment of human cells and/or tissues. This model represents the landmark experiment that sparked further development of humanized mice for the study of human hematopoiesis. In the late 1980's both the SCID-hu Thy/ Liv $[60,61]$ and the hu-PBL-SCID $[62,63]$ mouse models were developed, where human thymus and liver and human peripheral blood mononuclear cells (PBMCs), respectively, were successfully engrafted. In 1995, the SCID mutation that had been utilized in other models was crossed with the non-obese diabetic (NOD) mouse model resulting in an animal (NOD-SCID) that demonstrated a marked increase in engraftment potential. These animals could accept the xenotransplantation of blood 
cells forming fetal liver, bone, thymus, and lymphoid cells [60,61,64-67]. Further adjustments have been made to this NOD/SCID model over time in order to continue to increase the extent and efficiency of humanization that could be achieved, resulting in the development of the NOD/SCID $\beta 2$-microglobulinnull and the NOD/SCID IL2r $\gamma^{\text {null }}$ mouse models $[68,69]$. Recently, a mouse model defective in common $\gamma$ chain $\left(\gamma_{c}\right)$ receptor for IL-2, IL-7, IL-15 and other cytokines, was made from the recombinase activating gene (Rag) knockout mice [70-73] as well as from the NOD-SCID mouse [71]. These Rag- $-1-\gamma_{c}^{-/-}$and NOD-SCID $\gamma_{c}{ }^{\text {null }}$ (NOG) mice have no functional T, B, or NK cell activity in addition to being superior to the SCID mice, due to the lack of a leaky mutation. All of these mouse models have developed over time to various degrees of accuracy and efficiency of xenotransplantation of human cells/tissues as well as the development of a functioning human immune system. Due to differences in experimental approach and limitations on life-span, each mouse strain is suitable for a specific kind of experimental model. Here, we focus on the development of each of these models for the study of human retroviral infection, i.e., with HIV-1 and HTLV-1. The comparison of all of these models in historical context, as illustrated in Figure 1 , provides extensive background information and reviews the recent literature. In addition, the implication of these humanized mouse models in the study of retroviral coinfections with other pathogens will be addressed.

\section{Graft vs. Host disease in humanized mouse models}

An inherent problem associated with the engraftment of any foreign tissue into another host is the risk of incompatibility, either rejection of the graft by the host or graft vs. host disease (GVHD). GVHD is an interesting and especially relevant syndrome that is often observed in organ and bone marrow transplants when functional immune cells in the transplanted tissue or fluid recognize the host cells and tissue as foreign and subsequently initiate an immunologic response against the host. This response quickly spreads to become an established systemic attack and results in the death of the host. In the context of xenografted small animals, how is it that these humanized mice can support and establish a functioning human immune system without exhibiting any GVHD symptoms? One possible answer is found in the Thy/Liv

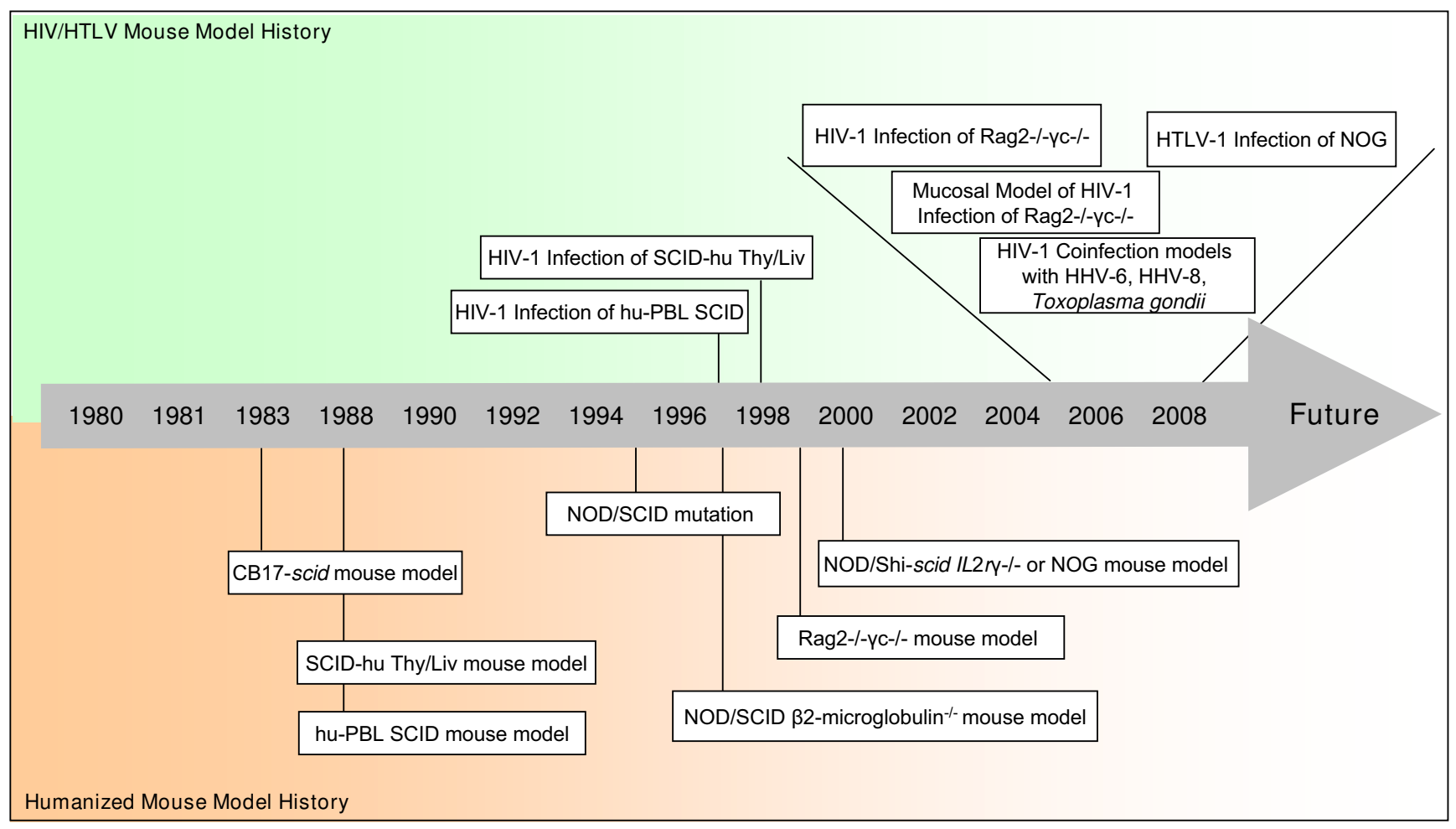

\section{Figure I}

A timeline of humanized mouse model development and retroviral research. A highlight of the noteworthy events of humanized mouse model system development over the past 30 years. The bottom half of the timeline denotes the emergence of key humanized mouse models. The top half of the timeline denotes the application of the models to HIV-I and HTLVI research. The area from 2005 to 2009 has been expanded to show the increase in retroviral development within a short time period. 
model which has proven particularly useful in preventing GVHD due to the complete exclusion of mature CD3+ T cells, a phenomenon that can be mimicked clinically with some success. Additionally, the presence of the fetal thy/ liv organ allows for innate maturation of human CD4+ and CD8+ T cells in the context of the animal's own immune system.

In general, the proliferation of human cells in these humanized mouse models is clearly evident; however, the functionality of the system is under scrutiny. Uittenbogaart $e t$ al. have shown that the maturation of engrafted human T cells occurs within the microenvironment of the SCID mouse; however, the possibility of phenotypic changes, especially on cell-surface markers is evident [74]. It is possible that these animals may actually exhibit an atypical GVH reaction, where the xenografted human $\mathrm{T}$ cells become anergic within the mouse [75]. The CD4+ and CD8+ populations of $\mathrm{T}$ cells in particular, exhibit anergy in that they are not activated to secrete cytokines after stimulation with CD3; however, when grown in vitro, the chimeric CD4+ cells were able to display anti-SCID mouse reactivity [75]. These data suggest that although the SCID mouse is able to support a human T cell system the immune system may not always be properly functional. It has been proposed that up to three weeks post engraftment, a majority of the injected human cells will survive, proliferate, and mature; however, after this time, anti-mouse-reactive clones that are selected for and the engrafted immune system becomes nonfunctional [63]. Finally, exploring the apparent contradictory lack of GVDH in these model systems, it is important to note that GVHD typically refers to events associated with allogenic grafts; the syndrome is not as well defined, understood, or quantified in xenogenic grafts.

\section{Humanized murine models of HIV-I infection SCID-hu Thy/Liv Mice and HIV-I}

The discovery of the severe combined immunodeficiency mutation (scid) in the CB17-scid/scid mice strain in 1983 gave rise to the development of the SCID-hu Thy/Liv model, the first reported attempt of murine humanization in 1988 [61]. The now well characterized SCID-hu Thy/ Liv model has been described as a valuable in vivo system for the developing field of translational research due to its multi-functionality in areas of experimental research [75]. The SCID-hu Thy/Liv model is a heterochimeric small animal system where severe combined immunodeficient CB17-scid (SCID) mice with a phenotype characterized by the absence of mature $\mathrm{B}$, $\mathrm{T}$ cells and radiation sensitivity $[59,76]$ are transplanted with human fetal thymus and liver tissues under the kidney capsule. The co-implanted human thymus and liver tissues fuse in the formation of a conjoint organ (Thy/Liv) that continuously produces long-term ( 6 months to $\geq 12$ months) human hematopoi- etic CD34+ progenitor stem cells as well as normal mature human lymphocytes with a majority $(>70 \%)$ of CD4/CD8 double-positive (DP), CD4+ and CD8+ single-positive (SP), and double-negative (DN) T cells [77] (Table 2). After implantation, the SCID-hu Thy/Liv mice develop peripheral blood lymphocytes (PBL) consisting mostly of naive $\mathrm{CD} 4+$ or $\mathrm{CD} 8+\mathrm{SP} \mathrm{T}$ cells that display migration from the human thymus and liver engraftment to the periphery in a time lapse of 3-4 weeks post-surgery; however, there is no significant systemic repopulation of human $\mathrm{T}$ cells and practically no human B cells, monocytes, macrophages, or DCs [78]. The SCID-hu Thy/Liv mice have been appropriately used for tissue transplants, human hematopoiesis analysis and the study of HIV-1 infection pathophysiology, as well as the in vivo efficacy of immunomodulatory, drug and gene therapies [60,79-81]. Overcoming some challenges of these reconstituted SCIDhu mice, the model allows for the production of singledonor large cohorts that increase statistical significance of comparative pre-clinical drug trials [82-84].

An intrathymic or intranodal injection of HIV-1 into the SCID-hu Thy/Liv mouse results in an infection that mimics human viral tropism; that is, preferential infection of CD4+ T cells [85]. Immunohistological staining revealed infected cells primarily in the thymus cortical regions, spreading later through the entire heterochimeric thymus as the infection progressed $[77,86]$. Interestingly, only primary isolates of HIV-1 (JR-CSF) derived from patients were permissive for viral replication in the SCID-hu Thy/ Liv mouse as compared to a lab strain (IIIb) which produced no detectable viral RNA. After the intravenous or intraorgan infection with HIV-1, only human cells were infected and from these, only CD4+ T and myelomonocytic cells. Initial HIV-1 infections of SCID-hu Thy/Liv animals resulted in a near-eradication of $\mathrm{CD} 4+/ \mathrm{CD} 8+\mathrm{DP}$ thymocytes and a decrease in the CD4+ SP T cell population of the human implanted tissue $[77,87,88]$, a depletion shown to be reduced upon treatment with several anti-HIV compounds [89-93] (Table 3).

Significant disadvantages of the SCID-hu Thy/Liv, due to suboptimal conditions for the establishment of a complete human immune system in vivo, have propelled the development of improved models. Largely, the CB17-scid is known to exhibit high levels of innate immune and NK cell activity, and age-related spontaneous generation of mouse B and T cells that in turn lowers the levels of successful engraftment of human tissue [76,94,95]. In 1994, in an attempt to correct the low count of human PBLs, Kollman et al. implanted greater amounts of Thy/Liv tissue beneath both kidney capsules, in effect producing higher levels of detectable circulating human T cells and a consequent variation to this model [96]. Noteworthy, the surgical procedure for implantation of the human fetal 
Table 2: Defining Characteristics of Humanized Mouse Models

\begin{tabular}{|c|c|c|c|c|c|}
\hline Model & $\begin{array}{l}\text { Human Cells } \\
\text { Engrafted }\end{array}$ & Irradiation & $\begin{array}{l}\text { Demonstrated } \\
\text { Human Cells }\end{array}$ & Humanized Tissues & Length of Detection \\
\hline SCID-hu Thy/Liv & Fetal thymus and liver & No & $\begin{array}{l}\text { D4/CD8 DP, SP, DN, T } \\
\text { cells in peripheral blood }\end{array}$ & $\begin{array}{l}\text { Peripheral blood, fused } \\
\text { thy/liv organ }\end{array}$ & 6 to $\geq 12$ months \\
\hline hu-PBL SCID & IP PBMCs & No & $\begin{array}{l}\text { CD4/CD8 SP T cells, } \\
\text { CD3+ T cells, } \\
\text { monocytes, NK cells, and } \\
\text { B cells }\end{array}$ & $\begin{array}{l}\text { Lymph nodes, spleen, } \\
\text { liver, bone marrow }\end{array}$ & 6 months \\
\hline NOD SCID BLT & $\begin{array}{l}\text { Fetal thymus and liver, } \\
\text { fetal liver tissue-derived } \\
\text { CD34+ stem cells }\end{array}$ & Yes & $\begin{array}{l}\text { Mature T and B } \\
\text { lymphocytes, monocytes, } \\
\text { macrophages, and } \\
\text { dendritic cells }\end{array}$ & $\begin{array}{l}\text { Peripheral blood, liver, } \\
\text { lung, vagina, rectum, and } \\
\text { GALT }\end{array}$ & 22 weeks \\
\hline NOD SCID IL2r $\gamma^{-1-}$ & $\begin{array}{l}\text { CD34+ human cord } \\
\text { blood }\end{array}$ & Yes/No & $\begin{array}{l}\text { Myelomonocytes, } \\
\text { dendritic cells, } \\
\text { erythrocytes, platelets, } \\
\text { and lymphocytes }\end{array}$ & $\begin{array}{l}\text { Peripheral blood, spleen, } \\
\text { and bone marrow }\end{array}$ & $>300$ days \\
\hline $\operatorname{Rag} 2^{-1-} \gamma \mathrm{c}^{-/-}$ & $\begin{array}{l}\text { CD34+ human cord } \\
\text { blood }\end{array}$ & Yes & Dendritic, $T$, and $B$ cells & $\begin{array}{l}\text { Peripheral blood, liver, } \\
\text { spleen, bone marrow, } \\
\text { vagina, GALT }\end{array}$ & 190 days \\
\hline NOD SCID $\beta 2 m$ & $\begin{array}{l}\text { Transformed HTLV-I } \\
\text { cell lines, PBMCs from } \\
\text { HTLV-I infected patients }\end{array}$ & Yes/No & CD45+, CD3+, $T$ cells & $\begin{array}{l}\text { Peripheral blood, spleen, } \\
\text { lymph node, bone } \\
\text { marrow }\end{array}$ & 4 to 12 weeks \\
\hline $\begin{array}{l}\text { NOD SCID IL2r } \gamma \text { null } \\
\text { ("NOG") }\end{array}$ & $\begin{array}{l}\text { Transformed HTLV-I } \\
\text { cell lines, PBMCs from } \\
\text { HTLV-I infected patients }\end{array}$ & No & CD4+, CD8+ T cells & $\begin{array}{l}\text { Liver, spleen, lung, } \\
\text { kidney }\end{array}$ & $\mathrm{N} / \mathrm{A}$ \\
\hline
\end{tabular}

thymus and liver tissues requires skilled researchers for coimplantation as well as systemic support of the developing organoid [77].

Additionally, this model is not an appropriate scaffold for the study of the humanized immune system or HIV-1 infection of mucosal tissues such as vaginal, rectal, or
GALT largely due to the confinement of most of the engrafted human cells to the developed organoid [78]. The Thy/Liv model of HIV-1 infection still provides an appropriate platform for the evaluation of antiretroviral therapies and treatments [78]. Of particular novelty is the testing and optimization of the efficacy of such therapeutics within an intact HIV-1 infected human target organ

Table 3: Defining Characteristics of Retroviral Infection in Humanized Mouse Models

\begin{tabular}{|c|c|c|c|c|c|c|}
\hline Model & Strain of Virus & $\begin{array}{l}\text { Method of } \\
\text { Infection }\end{array}$ & $\begin{array}{l}\text { Active Viremia } \\
\text { (after how long) }\end{array}$ & Infected Tissues & $\begin{array}{l}\text { Depletion of T } \\
\text { Cells? }\end{array}$ & $\begin{array}{c}\text { Neutralizing } \\
\text { Ab? }\end{array}$ \\
\hline SCID-hu Thy/Liv & HIV-I (R5, X4) & IV or intraorgan & $\begin{array}{l}\text { Within a few } \\
\text { weeks }\end{array}$ & $\begin{array}{l}\mathrm{CD} 4+\mathrm{T} \text { and } \\
\text { myelomonocytic } \\
\text { cells }\end{array}$ & Yes & No \\
\hline hu-PBL SCID & HIV-I (R5, X4) & IP or intraorgan & Within 2 weeks & T cells, vaginal & Yes & Yes \\
\hline NOD SCID BLT & HIV-I (R5) & IP, vaginal, rectal & $\begin{array}{l}\text { Within a few } \\
\text { weeks }\end{array}$ & $\begin{array}{l}\text { Vaginal, rectal, } \\
\text { GALT }\end{array}$ & Yes & Yes \\
\hline NOD SCID IL2r $\gamma^{-1-}$ & HIV-I (R5, X4) & IP, IV & $\begin{array}{l}\text { Within a few } \\
\text { weeks }\end{array}$ & $\begin{array}{l}\text { Peripheral blood, } \\
\text { spleen, bone } \\
\text { marrow, thymus, } \\
\text { vaginal }\end{array}$ & Yes & Yes \\
\hline $\operatorname{Rag} 2^{-/-} \gamma c^{-/-}$ & HIV-I (R5, X4) & IP, vaginal, rectal & Within 2 weeks & $\begin{array}{l}\text { Peripheral blood, } \\
\text { thymic, splenic, } \\
\text { and lymphoid } \\
\text { tissues, vaginal and } \\
\text { rectal mucosa }\end{array}$ & Yes & Yes \\
\hline NOD SCID $\beta 2 m$ & $\begin{array}{l}\text { HTLV-I } \\
\text { (transformed cell } \\
\text { lines) }\end{array}$ & IP, IV & $\begin{array}{l}\text { Between } 3 \text { and } 12 \\
\text { weeks }\end{array}$ & $\begin{array}{l}\text { Peripheral blood, } \\
\text { spleen, lymph } \\
\text { nodes, bone } \\
\text { marrow }\end{array}$ & $\mathrm{N} / \mathrm{A}$ & N/A \\
\hline $\begin{array}{l}\text { NOD SCID IL2r } \gamma \\
\text { null ("NOG") }\end{array}$ & $\begin{array}{l}\text { HTLV-I } \\
\text { (transformed cell } \\
\text { lines) }\end{array}$ & IP, IV & Within 2 weeks & $\begin{array}{l}\text { Peritoneal cavity, } \\
\text { spleen, peripheral } \\
\text { blood }\end{array}$ & N/A & N/A \\
\hline
\end{tabular}


[78]. Despite the generation of improvements as mentioned above, this humanized mouse model still maintains critical importance primarily for new antiretroviral pharmacological studies, pre-clinical testing and to a lesser extent, for the study of viral mechanisms.

\section{SCID-hu PBL Mice and HIV-I}

The SCID-hu Thy/Liv mouse was accompanied by the development of the SCID-hu PBL (humanized-peripheral blood lymphocyte) mouse model, generated by the i.p. injection of PBMCs from healthy human adults into SCID mice [62]. These PBMCs, upon successful engraftment, tend to survive at least six months mainly in the lymph nodes, spleen, bone marrow, and genital mucosa of the SCID-hu PBL mouse $[62,97,98]$. These mice exhibit spontaneous secretion of human immunoglobulin (IgG) and can produce a specific human antibody response when induced with an immunization of tetanus toxoid [62]. At one day post injection, there is a large neutrophil recruitment and an induced expression of murine cytokine mRNA (IL-1 $\beta$, IL-4, IL-6, IL-10, IL-12, TNF- $\alpha$ and IFN- $\gamma$ ) that occurs in the mouse peritoneal cavity [99]. After the first three weeks of expansion of the PBL in the peritoneal cavity, the human leukocytes, specifically CD4+ or CD8+ SP T cells expressing alpha/beta T-cell receptors, begin to appear in the mouse liver and spleen [100]. In this model, the CD4+ and CD8+ cells are considered to be xenoreactive, mature, but anergic T cells. These single positive Tcells have been shown to express HLA-DR and CD45RO $[100,101]$. TTThe CD45RO antigen can be used as a marker for either activated or memory T-cells. There also seems to be an expansion of CD3+ T cells; however, significantly smaller numbers of human monocytes, NK cells, and B cells secrete human immunoglobulin and exhibit a secondary antibody response [102] (Table 2).

In terms of utility, the SCID-hu PBL mouse has been commonly used to study anti-HIV therapy, vaccine efficacy, as well as viral cytopathogenicity in vivo $[101,103,104]$. The SCID-hu PBL mice have been successfully implanted with CCR5- and CXCR4- tropic PBMCs-associated HIV-1 from infected individuals to an efficiency where sustained viral replication was detected by the presence of viral RNA in the plasma as well as the progressive depletion of CD4+ T cells, indicative of an acute HIV-1 infection [105]. Since SCID-hu PBL mice have a large peritoneal cavity, a large volume of CD4+T, CD8+T, and NK cells as well as complement components can exist in these mice after injection of human PBMCs and thus interaction with HIV-1 neutralizing antibodies can be tested to evaluate pre- and post- exposure protection [104] (Table 3). Administration of a high dose of the neutralizing human monoclonal antibody IgG1b12, which targets the human gp120/CD4 binding site blocked viral entry $[106,107]$ and subsequently was able to protect the host from developing high plasma viremia $[106,107]$. The Rmu5.5 anti-HIV antibody was also able to protect the mice from the replication of primary isolates of HIV-1 when injected i.v. [108]. These studies demonstrated the usefulness of the SCID-hu PBL mouse as an effective model of antibody induction against HIV-1 infection; however, the studies did not show any effects of passive immunizations in mice against established HIV-1 infection.

Although the SCID-hu PBL mice have shown susceptibility to HIV-1 infection, this model does not represent a robust scaffold for genital-mucosal infection and transmission. Interestingly though, the infection of human PBLs engrafted within the vaginal tissues of these mice has been shown when the mice are pretreated with progestin to thin the vaginal epithelium $[78,97,98]$. This method of infection was utilized to enhance mucosal HIV-1 transmission and to evaluate the efficiency of vaginal topical microbicides.

As an attempt to improve on the existing SCID-hu PBL model, Yoshida et al. recognized the lack of human antigen presenting cells, such as DCs, as well as the presence of a normal human immunological lymphatic system in these mice [109]. To this end, normal human PBMCs were injected directly into the spleens of SCID mice to produce a hu-PBL-SCID-spl mouse; a hybrid of the SCID-hu PBL mouse. The mice were also implanted with human mature DCs that were treated with either inactive HIV-1 strains or control ovalbumin and then challenged with an i.p. injection of R5 HIV-1 $1_{\text {IR-CSF}}$. This challenge resulted in a protective immune response and manifested the presence of neutralizing antibodies as well as other anti-HIV protective factors. These particular soluble factors were subsequently found to be produced by CD4+ T cells and are R5 viral suppressive factors [110].

\section{NOD-SCID models}

The development of the NOD-SCID mouse model especially the CB17-prkdcscid mice has been described as one of the most important breakthroughs in the humanized mouse model field. The NOD-SCID mouse was created by transferring the SCID mutation into a non-obese diabetic (NOD) mouse which is often used as a model for insulindependent diabetes [111]. For more than a decade, NODSCID mice have been the "gold standard" for studies of human hematolymphoid engraftment in small animal models. The enhanced ability of NOD-SCID mice to engraft with human hematolymphoid tissues as compared with CB17-SCID mice was reported in 1995 by the Schultz group [67]. Mice in the NOD genetic background exhibit deficiencies in NK cell activity, at least partially due to impairment of the activating receptor NKG2D [112]. They are also impaired in complement activation due to C5 deficiency [113], and finally they lack LPS- 
induced production of IL-1 by macrophages [67]. All these features contribute to these mice showing improved engraftment of human PBMCs and hematopoietic stem cells $[64,66,114,115]$ (Table 2). A downside to the NODSCID model is the tendency of the mice to develop thymic lymphomas which can compromise the life-span of the animals $[111,116]$.

Koyanagi et al. described NOD-SCID as a novel immunodeficient mouse strain based its genetic background [117]. In particular, the authors described the NOD-SCID huPBL mouse where engraftment of human PBLs resulted in defective T, B and NK cell populations which can model a high level of HIV-1 infectable human cells. Upon infection with HIV-1, these mice exhibited high levels of viremia, as well as detectable viral RNA in infected cells, and free virions in the blood stream. This model also exhibited HIV-1 infection in vital organs such as the liver, lungs, and brain. The uniqueness of this model is derived from its lack of NK cells; therefore, the lack of innate immunity allows for the presentation of a susceptible model for the development of HIV-1 viremia as well as for multiple organ pathogenesis [117].

In the bone marrow/liver/thymus, or "BLT" mouse model, NOD-SCID mice are implanted with fetal thymic and liver organs, similar to the SCID hu Thy/Liv model [118]. The mice are then sublethally irradiated and transplanted with fetal liver tissue-derived CD $34^{+}$stem cell suspension. In this model, the mice essentially undergo a bone marrow transplant to complement the human fetal thymus/liver implants [118]. This mouse model results in a large number of reconstituted human mature $\mathrm{T}$ and $\mathrm{B}$ lymphocytes, monocytes, macrophages, and DCs in lymphoid organs [118]. This model also exhibits systemic populations of a large number of human B cells, monocytes, macrophages, and DCs, in addition to the infiltration of the liver, lung, and GI tract with human immune cells (Table 2). The humanized BLT mouse is an attractive scaffold for HIV-1 research in that the robust systemic reconstitution of the mouse with human cells is possible due to the education of human $\mathrm{T}$ cells within the engrafted thymus, as well as the maturation of human hematopoietic cells. This system has shown functional immune responses in the form of immunoglobulin production, T cell receptor expression, and cytokine production in response to various toxins and to the xenografting itself [78]. The BLT mouse in particular contains HIV-1 susceptible populations of human cells within the GI tract as well as in the vaginal and rectal tissues [119] (Table 3). Human mucosal cells within the BLT mice are targets for mimicking HIV-1 induced CD4+ T cell depletion seen in human GALT $[78,119]$. In particular, the reconstituted DCs found in the gut epithelium are lineage negative, HLA-DRbright $\mathrm{CD} 11 \mathrm{c}^{+}$cells that are also found within the human vagina, ectocervix, endocervix, uterus, and lungs [78]. The reconstitution of the female genital tract in the BLT mice specifically provides an ideal model for the investigation of vaginal HIV-1 transmission; an infection which results in systemic dissemination of the virus in the animal.

\section{NOD/SCID IL2 $r \gamma^{-1-}$ mouse model and HIV-I infection}

The NOD/SCID model also served as the basis for the development of another breakthrough animal model. This time the target for mutation was the interleukin 2 receptor common gamma chain $\left(I L 2 r \gamma^{-/}\right)$since a defect here is responsible for the human manifestation of $\mathrm{X}$ linked SCID. This mutation resulted in a significant reduction in both the innate and the adaptive immune functions and has been utilized in several different strains for the purposes of investigating the benefits of humanization [69]. In particular, the NOD/Shi-scid IL $2 r^{-/}$or NOG mouse was developed in 2000 and Ito et al. demonstrated its success with efficient engraftment of human hematopoietic stem cells [71]. Shultz et al. used a similar approach to establish the NOD/LtSz-scid IL2r $r \gamma^{-/}$mouse model [72]. These two models differ in their use of distinct NOD substrains as well as the choice of the IL2r $r \%$ mouse [68]. The NOG animal is the product of a cross between the NOD/Shi-scid mouse with an IL2r $r-$ - mouse that has a defect in exon 7. Conversely, Shultz's model is the result of the NOD/LtSz-scid animal in combination with an IL2r $\gamma^{-/}$mouse that has a defect in exon 1 [68]. Thus far no significant differences in engraftment efficiency have been observed between the two animals, and they are considered to be comparable choices for use in investigations requiring a humanized model [68] (Table 2).

These mouse models have served as excellent tools for conducting various HIV-1 studies. This model was first shown to support human hematopoiesis by Ishikawa et al. who transplanted newborn NOD/SCID IL $2 r \gamma^{-/}$mice via a facial vein with purified human CD34+ cord blood cells [70]. The cells were readily reconstituted and differentiated into mature myelomonocytes, DCs, erythrocytes, platelets, and lymphocytes. This humanized model was improved upon, and it was shown that CD4+T cells in the peripheral blood, spleen, and bone marrow expressed both CXCR4 and CCR5 antigens and showed a long-lasting viremia after infection with HIV-1 viral isolates specific for both receptors [120]. The infected animals also produced both anti-HIV Env and anti-HIV Gag specific antibodies indicating a high sustained rate of viral infection. The engraftment and infection procedures employed by these studies resulted in an infection lasting only 43 days, after which the animals died; however, when the CD34+ cells were transplanted without myeloablation 
methods, the mice were able to survive for longer than 300 days [121] (Table 3). The establishment of a stable HIV-1 infection and a steady decline in CD4+ T cell counts resulted in one of the most efficient humanized mouse models of HIV-1 infection to date.

\section{Humanized Rag2 ${ }^{-I-} \gamma_{c}^{-l-}$ Mice and HIV-I infection}

The humanized NOD-SCID models are based on the SCID mutation which can result in a leakiness marked by low level production of mouse immunoglobulins and Tcell receptors over time. Additionally, these mice have a significantly decreased viability due to the development of lethal thymic lymphomas in as little as 5 months and susceptibility to GVHD. Pertaining to HIV-1 infection, inadequate sustained hematopoietic cell populations in these mice allows for only the study of acute HIV-1 infection rather than the chronic, latent infection observed in HIV-1 infected individuals. Therefore, the development of a more stable humanized mouse model, exhibiting a functional human immune system, was needed to address the shortcomings of the hu-SCID models. This was accomplished through the development of the Rag2 $-1-\gamma_{c}^{-1-}$ mice which are completely devoid of all T, B, and NK cells $[122,123]$. These mutant mice were created by crossing homozygous recombinase activating gene 2 (Rag2) knockout mice with homozygous common cytokine receptor $\gamma$ chain $(\gamma \mathrm{c})$ knockouts $[122,123]$. The Rag2 mutation results in the lack of maturation of thymusderived $T$ cells and peripheral $B$ cells where the $\gamma \mathrm{c}$ mutation results in the lack of the functional subunit of the interleukin-2 (IL-2), IL-4, IL-7, IL-9 and IL-15 receptors, preventing the development of lymphocytes and NK cells $[122,123]$ (Table 2). The Rag2 knockout is not a leaky mutation; it does not result in spontaneously forming tumors; nor does it confer radiation-sensitivity to the mice as the SCID mutation does. Therefore, the Rag $2-\gamma_{c}{ }^{-1-}$ mouse may be an ideal scaffold for repopulation of the animal with human hematopoietic cells.

A significant advance in the humanized mouse model field was marked by the successful xenotransplantation of immunodeficient mice with human CD34+ hematopoietic stem cells (HSC). Reconstitution of human immune

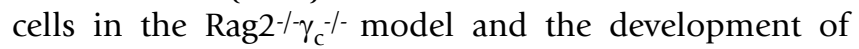
human adaptive immunity has been shown by Traggiai $e t$ al. [73]. BALB/c Rag $2^{-/-\gamma_{c}-/-n e o n a t e s ~ w e r e ~ s u b l e t h a l l y ~ i r r a-~}$ diated, injected intrahepatically (i.h.) with CD34+ human cord blood stem cells 4-12 hours post irradiation, and allowed to reconstitute for a period of 26 weeks. Transplanted mice exhibited lymph node development at 8 weeks of age as well as the presentation of CD45+ human hematopoietic cells. The transplanted mice also developed human DC, T, and B cells, and engrafted human cells were found in the bone marrow and spleen. The investigators also showed that the engraftment was suffi- cient to stimulate a human immune response when exposed to tetanus toxins and Epstein-Barr virus. This was the first humanized mouse model to show any kind of normal human cytotoxic immune response. Gimeno et al. utilized the same mouse strain and a similar set of experiments to model the knockdown of tumor suppressor genes (i.e. p53) and monitor the development of hematopoietic cells in vivo [124]. Here, Rag $2^{/-} \gamma_{c}{ }^{-/}$neonates were sublethally irradiated, injected i.p. with CD34+ human cells isolated from fetal liver and allowed to reconstitute [124]. The authors also investigated the age-dependence of engraftment in these mice and found that neonates can form $80 \%$ human cells, while one-week old animals can form 30\% human cells, and two-week old animals can form $10 \%$ human cells at 8 weeks post implantation $[116,124]$. The preference for using neonates when reconstituting human cells is most likely due to a lesser developed murine thymus as compared to older mice or due to macrophages or neutrophils being less developed and conferring less resistance in newborns $[116,124]$. Using newborn Rag2 $-\gamma_{c}-\gamma_{-}$animals, this study showed greater than $60 \%$ human cell engraftment in peripheral blood leukocytes and liver, and greater than 50\% human cell engraftment in spleen and bone marrow $[116,124]$. This significant improvement in xenotransplantation in the Rag $2-\gamma_{c}{ }^{-/}$model compared to the hu-SCID model provides a suitable environment to study infectious diseases and other maladies in a reliable small animal model.

The humanized Rag2 ${ }^{-}-\gamma_{c}-{ }^{-}$scaffold is an ideal system to study HIV-1 pathogenesis due to the presence of an intact human immune system and its ability to support multilineage hematopoiesis. Two groups published the first evidence that this humanized mouse model can support a sustained HIV-1 infection $[125,126]$. The Baenziger et al. study utilized the Traggiai method of xenotransplantation into Rag $2-1-\gamma_{c}-1-$ animals, and at $10-28$ weeks of age the animals were infected i.p. with CCR5-tropic YU-2 or CXCR4-tropic NL4-3 HIV-1 viral strains $[73,125]$. Both HIV-1 strains were able to produce a chronic infection of up to 190 days as well as an initial acute burst phase of viral replication as detected by plasma viral RNA [125]. This group observed some strain-specificity in terms of CD4 T cell depletion and thymic infection. The CXCR4tropic infected mice exhibited a marked depletion in CD4 $\mathrm{T}$ cell levels in the blood as compared to the CCR5-tropic strain, whereas the latter strain was able to infect the thymus of these animals almost exclusively. The Berges et al. study, which was focused on testing the permissiveness of this model to HIV-1 infection, was also performed using the xenotransplantation method of Traggiai et al. into conditioned neonatal BALB/c Rag2 $-\gamma_{c}-{ }^{-/}$animals [126]. At 16 weeks post engraftment, thymic, splenic, and lymphoid tissue samples were taken from an animal and successfully infected with an X4-tropic NL4-3 HIV-1 reporter 
virus ex-vivo as measured by p24 ELISA. As the engrafted human cells were infectable, an in vivo infection was subsequently performed i.p. with HIV-1 X4-tropic NL4-3 or R5-tropic BaL viruses and sufficient levels of viral DNA was detected in the blood at up to 30 weeks post infection. This infection model also exhibited CD4 T cell depletion in the animals, a characteristic of chronic HIV-1 infections in humans. This study proved that the Rag2-/- $\gamma_{c}^{-/-}$humanized mouse model can support an active infection in vivo and provide characteristic symptoms of viremia as seen in humans. These two studies were confirmed by Zhang et al. who reported that CCR5 and CXCR4 are both expressed on the reconstituted human $\mathrm{T}$ cells and peripheral lymphoid organs of this humanized mouse model [127]. They also reported that the HIV-1 infection in these mice persists for at least 19 weeks and that this model can serve to recapitulate HIV-1 immunopathogenesis.

Once the HIV-1 humanized mouse model was established in Rag2 $/-\gamma_{c}^{-/-}$animals, multiple studies have improved upon the model through increased robustness of infection and the generation of infectable human cells. These mice were found to display both the Treg phenotype and functions of regulatory CD4+CD25+ T cells in vivo [128]. Specifically, it was found that the Treg cells and their interaction with the FoxP3 transcription factor (CD4+FoxP3+ cells) allow for the preferential infection by HIV-1 in the Rag2-/- $\gamma_{c}^{-/-}$animals. Gorantla et al. developed an alternative irradiation dosing of neonatal mice at the time of xenotransplantation [129]. They combined lowerdosage irradiation (400-cGy) with busulfan-mediated myeloablation (destruction of quiescent stem cells), to result in a stable chimerism. Additionally, they found that all components of the human immune system were present at 16 weeks of age; however, the maturation of the immune system was not functional until sometime between five and six months of age. In terms of functional HIV-1 infection and viremia in this study, a low dose of HIV-1 C1157 was able to sustain a stable infection for at least eight to ten weeks. Additionally, infection with HIV1 ADA resulted in the expansion of CD8+ cells, activation of B cells, and physical changes in the lymph nodes, similar to what occurs in human HIV-1 patients. A study by An et al. recently described similar successes in infecting the Rag2 $/-\gamma_{c} /-$ model with a reconstituted human immune system with R5 HIV-1 isolates [130]. Their results were in accordance with previous studies as they were able to detect virus in HIV-1 infected animals by co-culturing infected cells with non-infected cells in vitro as well as observing a decrease in the CD4+/CD8+ ratio as early as two weeks post-infection. With a low dose HIV-1 infection, this group detected B cell production of IgM and IgG, but were unable to detect an antibody response against HIV-1 antigens. Similarly, Van Duyne et al. showed suc- cessful infection of differentiated human CD45+ lymphocytes in their reconstituted Rag2 ${ }^{-/-} \gamma_{c} /-$ model by ex-vivo infection with T-tropic or macrophage-tropic HIV-1 viruses [131] (Table 3). They also investigated the effect of inhibitors, i.e., AZT, Cyc202, and Tat peptide analogs on viral production in the Rag2 ${ }^{-/} \gamma_{c}-/$-model. In HIV-1 infected and treated animals, viral DNA was still observed; however, there was a marked decrease in Gag DNA/RNA as compared to untreated animals. Importantly, this model is now being investigated for the efficiency of RNAi gene therapy against HIV-1 infection. Ter Brake et al. recently evaluated the inhibitory effect of a shRNA against Nef protein in HIV-1 infected Rag $2^{-/-} \gamma_{c}^{-/-}$animals [132]. The shRNA was transduced into the human hematopoietic stem cells prior to xenotransplantation, and the cells were allowed to differentiate into a normal percentage of cell subsets. Mature human CD4+ T cells were infected ex vivo with HIV-1, and a marked inhibition of viral replication was seen in the cells from the animals that received RNAi therapy. This study has very important implications for further experiments exploring RNAi as a therapeutic method.

The i.p. and i.v. methods of HIV-1 infection suffice for establishing a strong infection in these mouse models; however, they are not the natural routes of HIV-1 exposure in humans. Therefore, some recent studies have investigated the proficiency of these humanized mouse models in rectal and vaginal transmission. Berges et al. investigated the efficiency of transmission and infection of both $\mathrm{R} 5$ and $\mathrm{X} 4$ tropic HIV-1 viruses via both vaginal and rectal routes in the humanized Rag2 $/ \gamma_{c}-/$ mice [133]. Interestingly, not only did these humanized animals contain susceptible human cells in both the rectal and vaginal mucosa, these animals were readily infected with HIV-1 through intravaginal or intrarectal exposures [133]. A more efficient systemic infection was seen with the R5 mucosal infection as compared to the X4-HIV; however, more importantly, both viruses were able to infect the animals without mucosal abrasion or other means that are designed to make the animal more susceptible [133]. Interestingly, an opposing study was recently published where it was determined that the Rag2 ${ }^{-/} \gamma_{c}{ }^{-/-}$animals are not suitable for rectal transmission of HIV-1 [134]. Humanized Rag $2^{-/} \gamma_{c}-/$ animals were exposed rectally with both cell-free and cell-associated HIV-1 but the resulting viral load was negative as compared to animals infected via the traditional i.p. route [134]. Even upon various proinflammatory stimuli to increase the animals' susceptibility to HIV-1 infection, there was still a very low transmission rate due to low levels of human cellular engraftment in the gastro-intestinal associated tissues and cells [134]. 


\section{Humanized murine models for HTLV-I infection HTLV-I Pathogenesis}

Another human retrovirus, Human T-cell leukemia virus type 1 (HTLV-1), has been identified as the causative agent of an aggressive form of adult T-cell leukemia (ATL) and HTLV-1-associated myelopathy/tropical spastic paraparesis (HAM/TSP) [135]. This virus has infected approximately 10 to 20 million individuals around the world, concentrating in several locations including, though not limited to, the islands of the Caribbean, the southwest area of Japan, and Central Africa [136,137]. Structurally, the virus is similar to other retroviruses in that it bears the gag, pol, and env genes, and long terminal repeats at the 5' and 3 ' ends [136]. One of the defining features of the virus is a region known as $\mathrm{pX}$ that encodes several regulatory proteins, including Tax, HBZ, and Rex $[136,138,139]$. In particular, Tax and HBZ have been associated with the clinical progression of disease in HTLV-1 infected individuals [136,140-143]. Successful transmission of the virus requires cell-to-cell contact and can be achieved through sexual intimacy, parenteral administration, or from a mother to infant via breast feeding. Expansion of the virus is achieved largely through proliferation of the infected cells, contributing to the clinical progression of disease [136]. Of the infected population, a small proportion will go on to develop ATL [137]. These individuals could experience a significant latency period of between 40 and 60 years. A diagnosis of ATL can be made using three criteria that include: lymphoid malignancy as proven through morphology and surface antigens, the demonstration of antibodies to HTLV-1 in the serum, and the use of Southern blot to shown integration of the HTLV-1 provirus $[136,137]$. The diagnosis of ATL can be further specified according to four unique subtypes with differing clinical characteristics that include smoldering, chronic, acute and lymphoma. The latter two, acute and lymphoma, are more aggressive and are typically associated with resistance to chemotherapy and subsequent poor outcomes. In the acute subtype, there may be an increase in ATL cell numbers, hepatosplenomegaly, lymphadenopathy, and skin lesions. The lymphoma subtype also demonstrates lympadenopathy throughout the body, although relatively few abnormal cells are seen in the peripheral blood. An individual diagnosed with one of these two subtypes will typically survive for an estimated duration of one year. The smoldering subtype demonstrates a low number of ATL cells with confirmed proviral integration in the peripheral blood. The chronic subtype has been shown to have a mildly elevated white blood cell count, as well as features similar to the acute type including hepatosplenomegaly, lymphadenopathy, and skin lesions. Often the chronic form will progress to acute or lymphoma with a mean survival time of about two years [144]. Cell-mediated immunity is involved in this disease process as evidenced by reports of co-infections with
Mycobacterium, cytomegalovirus, and Pneumocystis jiroveci [136]. Another interesting feature of the disease is the development of hypercalcemia in $70 \%$ of ATL patients. Hypercalcemia is thought to be the result of an increase in osteoclast activity and associated resorption of bone tissue that is mediated through factors such as macrophage colony-stimulating factor (M-CSF) and macrophage inflammatory protein-1 $\alpha$ (MIP-1 $\alpha$ ) $[82,84,136,145]$. Additionally, parathyroid hormonerelated protein (PTHrP) has also been implicated as an important factor in the development of HTLV-1 infection and subsequent transformation of T-lymphocytes [146]. In addition to progression to ATL, HTLV-1 infection can also lead to the development of HAM/TSP in some individuals. Mechanistically, HTLV-1 associated tumor development and its associated symptoms may be explained in part through the actions of the viral genes Tax and HBZ $[136,147,148]$. Currently, therapeutic options for HTLV-1 infection include combination chemotherapy, allogenic stem cell transplantation, monoclonal antibodies, NF- $\kappa B-$ targeting, or the use of Zidovudine with IFN- $\alpha$. Each of these approaches has limited success, and a reliable therapy remains to be found [136]. One other potential strategy is the dual use of cdk and NF- $\mathrm{kB}$ inhibitors [149]. The significance of this illness in combination with limited treatment options highlight the appeal of developing a successful small animal model for use in more clearly elucidating the pathogenesis of this infection as well as exploring therapeutic options.

\section{NOD/SCID $\beta 2$-microglobulinnull and NOD/SCID IL2r r $^{\text {null }}$}

As stated above, over the past 25 years science has seen the development of a variety of immunocompromised strains of mouse [69]. Most of these animals are the result of adjustments made to the 1983 CB17-scid mouse model. It was in this model that engraftment of human tissues was first observed in 1988. Ultimately, it was the development in the late 1990s of the NOD/SCID $\beta 2$-microglobulinnull mouse as well as the NOD/SCID IL2ry null mouse that have proven to be truly valuable for investigations related to the HTLV-1 infection $[68,69]$. At that time the CB17-scid mouse model was improved upon by addressing the residual innate immune function through the creation of a mutation at the locus for $\beta 2$ microglobulin $(\beta 2 \mathrm{~m})$; this mouse was subsequently known as the NOD/SCID $\beta 2$ microglobulin null mouse [64].

Investigation in the pathogenesis and potential treatment options related to HTLV-1 infection could be greatly enhanced by a useful small animal model. With the development of the humanized strains discussed above, the successful use of such a model became a realistic option. Early attempts to establish an HTLV-1 infection in vivo involved inoculation of the CB17-scid mouse model with PBLs or PBMCs from donors diagnosed with HTLV-1 
infections. These experiments were promising although limited in success due to engraftment inefficiencies and poor detection of viral integration [150,151]. Feuer et al. took a different approach when they used the previously mentioned SCID-hu Thy/Liv model to compare the engraftment achieved with either infected human hematopoietic progenitor CD34+ cells or in vitro transformed HTLV-1 infected cell lines SLB-1 and MT-2 [145]. This group showed that not only could human hematopoietic progenitor cells be infected via co-cultivation with cell lines transformed with HTLV-1 and HTLV-2, but upon inoculation into SCID-hu Thy/Liv mice, infection could be detected in biopsies from the thy/liv organ. When the same model was challenged using only the transformed cell lines SLB-1 and MT-2, infection could be detected in biopsies from the thy/liv organ, although levels were not as impressive as those achieved with the hematopoietic progenitor cells. These results pointed to a role for hematopoietic cells in infection [145]. However, the limitations associated with the SCID-hu Thy/Liv model, especially the lack of systemic infection, caused investigators to continue to look to other models. An important development in the use of PBMCs for establishing such models was demonstrated by Liu et al. in their use of different HTLV-1 infected cell lines. This group noted that a higher level of engraftment could be achieved through the use of an HTLV-1 transformed cell line as opposed to cell lines that were immortalized through transfection, which did not produce lymphomas in NOD/SCID animals [152]. A subsequent investigation by Tanaka et al. in 2001 made use of the somewhat enhanced $\mathrm{C} 3 \mathrm{H} / \mathrm{HEJ}$ model and involved inoculation with MT-2 cells, a human T-cell line that produces HTLV-1 virus [153]. These colleagues were able to demonstrate integration of the virus as well as an apparent concentration of infected cells in lymphoid tissue. Miyazato et al. took the next step in 2006 when they designed an experiment utilizing the NOG mouse model [154]. Their investigation involved inoculation with PBMCs in order to establish a human system, followed by inoculation with the MT-2 cell line to allow for the required cellto-cell transmission essential for HTLV-1 infection (Table $2,3)$. Important findings included the detection of an increased proviral load in both CD4+ and CD8+ T cells. Additionally, they were able to demonstrate that prophylaxis with the reverse transcriptase inhibitors Tenofovir and Azidothymidine was successful in preventing new HTLV-1 infection in these animals. Takajo et al. was able to achieve similar results in 2007 when they also established HTLV-1 infection in NOG mice through the inoculation of PBMCs from HTLV-1 infected individuals [155]. Although the approach was somewhat different, the group confirmed that these animals could harbor HTLV-1 infection; and they demonstrated the presence of detectable viral integration.
The establishment of a successful murine HTLV-1 infection model quickly presented the opportunity for the investigation of treatment options. A report by Ohsugi $e t$ al. explored the use of the NF- $\mathrm{B}$ inhibitor dehydroxymethylepoxyquinomycin (DHMEQ) as a therapeutic agent $[156,157]$. Ohsugi's group established a model for infection in the NOD/SCID $\beta 2$-microglobulinnull mouse by sublethally irradiating 7 to 10 week old animals and injecting them with transformed HTLV-1 cell lines the following day. This investigation used the NOD/SCID $\beta 2$ microglobulin ${ }^{\text {null }}$ mouse model to test the effectiveness of DHMEQ as a therapeutic option in HTLV-1 infection (Table 2, 3). Administration of DHMEQ showed increased survival and growth inhibition of ATL cells in animals that had been infected through inoculation with HTLV-1 producing cell lines. Another attempt to explore treatment options included a novel approach to detecting tumor growth. Shu et al. established a bioluminescent mouse model in the older CB17-scid model by infecting the animals with an ATLL cell line, RV-ATL, and a lentivirus harboring the luciferase gene [158]. These investigators were able to non-invasively measure the tumor growth and expansion which occurred in the recipient mice. Additionally, they tested both a bisphosphonate, zoledronic acid, and a protease inhibitor, PS-341. Both compounds demonstrated some level of success in reducing the development of tumors, as well as levels of parathyroid hormone-related protein (PTHrP) and macrophage inflammatory protein- $1 \alpha($ MIP- $1 \alpha)$ which are both indicators of humoral hypercalcemia of malignancy (HHM), a complication observed in $60 \%$ of HTLV-1 infected individuals [158]. A recent publication by Nitta et al. utilized a mouse model with a defect in NF- $\kappa \mathrm{B}$ inducing kinase (NIK) gene resulting in a phenotype of alymphoplasia $(a l y / a l y)$ [159]. These investigators used this model to evaluate the importance of NIK for establishment of HTLV-1 infection and associated pathology. Aly/aly mice were compared with $\mathrm{C} 57 \mathrm{BL} / 6 \mathrm{~J}$ and $\mathrm{BALB} / \mathrm{c}$ mice. All animals were inoculated i.p. with MT-2 cells, and PCR was used to evaluate proviral load. Aly/aly animals demonstrated dramatically lower proviral loads, suggesting that NIK plays an essential role in HTLV-1 infection and could serve as a potential target for therapeutic intervention [159]. Chen et al. utilized the NOD/SCID mouse inoculated with an ATL cell line, MET-1, in their investigation of the use of a histone deacetylase inhibitor, depsipeptide, along with daclizumab as a therapeutic option in the murine HTLV-1 infection model [160]. Their results also showed promising findings, in that both depsipeptide and daclizumab alone and when used in combination, were able to increase the survival of the animals [160].

The evolution of immunocompromised murine models has enabled an increasingly successful investigation of the 
pathogenesis of HTLV-1 infection. As recently as the past three years, experimentation using these humanized mice has generated informed insights into the mechanisms associated with HTLV-1 infection. Such investigations utilizing a wide range of mouse models and varying infection techniques promise to mimic HTLV-1 infection in humans.

\section{Humanized mice and co-infection models}

The humanized mouse models described above are clearly valuable research tools for the study of many kinds of disease. Additionally, a true model of HIV-1 infection in humans should not rule out the possibility and probability of co-infections amongst individuals. For example, Kaposi's sarcoma-associated herpesvirus (KSHV) or HHV8 has been shown to proliferate in the SCID-hu Thy/Liv model both in the presence and absence of a concurrent HIV-1 infection [161]. Similarly, Human Herpesvirus 6 (HHV-6) is a herpesvirus that infects immunosupressed people as a result of HIV-1 infection. HHV-6 has been evaluated as a potential cofactor in the progression of HIV-1 when co-infected as modeled through the SCID-hu Thy/Liv system [162]. Both HIV-1 and HHV-6 are able to replicate in the engrafted humanized thymus in this model, and further studies can be done to evaluate the interplay between these two viruses in vivo. Finally, a unique interaction exists between HIV-1 infected individuals who are also infected with the protozoan Toxoplasma gondii. In immunocompetent individuals, the parasite persists in the CNS as an asymptomatic chronic infection; however, in the presence of an HIV-1 infection, and the subsequent decrease in CD4+ cells, the T. gondii infection can reactivate and cause a disease known as Toxoplasma encephalitis [163]. Alfonzo et al. investigated the co-infection of T. gondii in SCID mice humanized with PBMCs from HIV-1 infected patients who had been treated with HAART for at least one year [163]. Mice humanized with blood from patients undergoing HAART were more resistant to parasitic infection than those mice without any antiretroviral treatment. This study concluded that there is a partial immune reconsistitution against parasitic infection in HIV-1 infected individuals undergoing HAART therapy. Future studies should also look at the impact of genital HSV-2 infection on the acquisition of HIV-1 in humanized mice since epidemiological human data suggest that prior HSV-2 infection significantly enhances sexual transmission of HIV in women.

\section{Conclusion}

Although still in its infancy, the field of humanized animal models holds enormous potential to grow as a primary research tool for human retroviral studies. Here we have reviewed the advances in this field over the past three decades, during which the technology and applications have grown exponentially. Future studies will most likely address how to increase the efficiency of mucosal infection in order to mimick the primary routes of HIV-1 transmission. The humanized mouse models also hold great promise for the development and testing of novel anti-retroviral therapies, bypassing the complications of larger animal (i.e., simian or human) studies. More generally, the humanized small animal model can benefit research in other human diseases such as cancers.

\section{Competing interests}

The authors declare that they have no competing interests.

\section{Authors' contributions}

Both RVD and CP contributed equally to this review.

\section{Acknowledgments}

This work was supported by grants from the George Washington University REF funds to FK, and Akos Vertes and by an NIH grant AI07I 903-0I to FK. It was also supported by grant from a subproject (MSA-06-437) provided by CONRAD, Eastern Virginia Medical School under a Cooperative Agreement (HRN-A-00-98-00020-00) with the United States Agency for International Development (USAID). Rachel Van Duyne is a predoctoral student in the Microbiology, Immunology, and Tropical Medicine Program of the Institute for Biomedical Sciences at the George Washington University.

\section{References}

I. Barre-Sinoussi F, Chermann JC, Rey F, Nugeyre MT, Chamaret S, Gruest J, Dauguet C, Axler-Blin C, Vezinet-Brun F, Rouzioux C, et al.: Isolation of a T-lymphotropic retrovirus from a patient at risk for acquired immune deficiency syndrome (AIDS). Science 1983, 220:868-7I.

2. Gallo RC, Sarin PS, Gelmann EP, Robert-Guroff M, Richardson E, Kalyanaraman VS, Mann D, Sidhu GD, Stahl RE, Zolla-Pazner S, et al.: Isolation of human T-cell leukemia virus in acquired immune deficiency syndrome (AIDS). Science 1983, 220:865-7.

3. Stevenson M: HIV-I pathogenesis. Nat Med 2003, 9:853-60.

4. Kahn JO, Walker BD: Acute human immunodeficiency virus type I infection. N Engl J Med I998, 339:33-9.

5. Perrin L: Primary HIV infection. Antivir Ther 1999, 3:13-8.

6. Mosier DE: How HIV changes its tropism: evolution and adaptation? Curr Opin HIV AIDS 2009, 4: I25-30.

7. Regoes RR, Bonhoeffer S: The HIV coreceptor switch: a population dynamical perspective. Trends Microbiol 2005, I 3:269-77.

8. Peters PJ, Duenas-Decamp MJ, Sullivan WM, Brown R, Ankghuambom C, Luzuriaga K, Robinson J, Burton DR, Bell J, Simmonds P, et al.: Variation in HIV-I R5 macrophage-tropism correlates with sensitivity to reagents that block envelope: CD4 interactions but not with sensitivity to other entry inhibitors. Retrovirology 2008, 5:5.

9. Centlivre M, Sala M, Wain-Hobson S, Berkhout B: In HIV-I pathogenesis the die is cast during primary infection. Aids 2007, 2l I-II.

10. Derdeyn CA, Silvestri G: Viral and host factors in the pathogenesis of HIV infection. Curr Opin Immunol 2005, I 7:366-73.

II. Benito JM, Lopez M, Soriano V: The role of CD8+ T-cell response in HIV infection. AIDS Rev 2004, 6:79-88.

12. Saksena NK, Wu JQ, Potter SJ, Wilkinson J, Wang B: Human immunodeficiency virus interactions with CD8+ $T$ lymphocytes. Curr HIV Res 2008, 6: I-9.

13. Petrovas C, Mueller YM, Katsikis PD: HIV-specific CD8+ T cells: serial killers condemned to die? Curr HIV Res 2004, 2: I53-62.

14. Picker LJ, Watkins DI: HIV pathogenesis: the first cut is the deepest. Nat Immunol 2005, 6:430-2.

15. Han Y, Wind-Rotolo M, Yang HC, Siliciano JD, Siliciano RF: Experimental approaches to the study of HIV-I latency. Nat Rev Microbiol 2007, 5:95-106. 
16. Zack JA, Arrigo SJ, Weitsman SR, Go AS, Haislip A, Chen IS: HIVentry into quiescent primary lymphocytes: molecular analysis reveals a labile, latent viral structure. Cell 1990, 6I:2 I3-22

17. Stevenson M, Stanwick TL, Dempsey MP, Lamonica CA: HIV-I replication is controlled at the level of $\mathrm{T}$ cell activation and proviral integration. Embo J 1990, 9:155I-60.

18. Vatakis DN, Kim S, Kim N, Chow SA, Zack JA: Human immunodeficiency virus integration efficiency and site selection in quiescent CD4+ T cells. J Virol 2009, 83:6222-33.

19. Jeeninga RE, Westerhout EM, ML van Gerven, Berkhout B: HIV-I latency in actively dividing human $\mathbf{T}$ cell lines. Retrovirology 2008, 5:37

20. Yamashita M, Emerman M: Retroviral infection of non-dividing cells: old and new perspectives. Virology 2006, 344:88-93.

21. Douek DC: Disrupting T-cell homeostasis: how HIV-I infection causes disease. AIDS Rev 2003, 5:172-7.

22. Preston BD, Poiesz BJ, Loeb LA: Fidelity of HIV-I reverse transcriptase. Science 1988, 242: I |68-7|

23. Menendez-Arias L: Molecular basis of fidelity of DNA synthesis and nucleotide specificity of retroviral reverse transcriptases. Prog Nucleic Acid Res Mol Biol 2002, 71:91-147.

24. Chen R, Quinones-Mateu ME, Mansky LM: Drug resistance, virus fitness and HIV-I mutagenesis. Curr Pharm Des 2004 10:4065-70.

25. Chen R, Quinones-Mateu ME, Mansky LM: HIV-I mutagenesis during antiretroviral therapy: implications for successful drug treatment. Front Biosci 2005, 10:743-50.

26. Mansky LM: HIV mutagenesis and the evolution of antiretroviral drug resistance. Drug Resist Updat 2002, 5:219-23.

27. Martinez-Picado J, Martinez MA: HIV-I reverse transcriptase inhibitor resistance mutations and fitness: a view from the clinic and ex vivo. Virus Res 2008, I 34:104-23.

28. Re MC, Bon I, Monari P, Gorini R, Schiavone P, Gibellini D, La Placa M: Drug failure during HIV-I treatment. New Microbiol 2003 , 26:405-13

29. Daar ES, Richman DD: Confronting the emergence of drugresistant HIV type I: impact of antiretroviral therapy on individual and population resistance. AIDS Res Hum Retroviruses 2005, $21: 343-57$

30. Zoeteweij JP, Blauvelt A: HIV-Dendritic cell interactions promote efficient viral infection of T cells. J Biomed Sci 1998, 5:253-9.

31. Samson M, Libert F, Doranz BJ, Rucker J, Liesnard C, Farber CM, Saragosti S, Lapoumeroulie C, Cognaux J, Forceille C, et al.: Resistance to HIV-I infection in caucasian individuals bearing mutant alleles of the CCR-5 chemokine receptor gene. Nature 1996, 382:722-5

32. Kedzierska K, Crowe SM: The role of monocytes and macrophages in the pathogenesis of HIV-I infection. Curr Med Chem 2002, 9: 1893-903

33. Tuttle DL, Harrison JK, Anders C, Sleasman JW, Goodenow MM Expression of CCR5 increases during monocyte differentiation and directly mediates macrophage susceptibility to infection by human immunodeficiency virus type I. J Virol 1998, 72:4962-9.

34. Kohler IJ, Tuttle DL, Coberley CR, Sleasman JW, Goodenow MM Human immunodeficiency virus type I (HIV-I) induces activation of multiple STATs in CD4+ cells of lymphocyte or monocyte/macrophage lineages. J Leukoc Biol 2003, 73:407-16.

35. Swingler S, Brichacek B, Jacque JM, Ulich C, Zhou J, Stevenson M: HIV-I Nef intersects the macrophage CD40L signalling pathway to promote resting-cell infection. Nature 2003, 424:2 I3-9.

36. Brenchley JM, Douek DC: HIV infection and the gastrointestinal immune system. Mucosal Immunol 2008, I:23-30.

37. Dandekar S: Pathogenesis of HIV in the gastrointestinal tract. Curr HIVIAIDS Rep 2007, 4: 10-5.

38. Kelleher $A D$, Zaunders II: Decimated or missing in action: CD4+ $T$ cells as targets and effectors in the pathogenesis of primary HIV infection. Curr HIVIAIDS Rep 2006, 3:5-12.

39. Mehandru S, Tenner-Racz K, Racz P, Markowitz M: The gastrointestinal tract is critical to the pathogenesis of acute HIV-I infection. J Allergy Clin Immunol 2005, I I 6:4 | 9-22.

40. Paiardini M, Frank I, Pandrea I, Apetrei C, Silvestri G: Mucosal immune dysfunction in AIDS pathogenesis. AIDS Rev 2008, 10:36-46.
4I. van Marle G, Gill MJ, Kolodka D, McManus L, Grant T, Church DL: Compartmentalization of the gut viral reservoir in HIV-I infected patients. Retrovirology 2007, 4:87.

42. Brenchley JM, Price DA, Schacker TW, Asher TE, Silvestri G, Rao S, Kazzaz Z, Bornstein E, Lambotte O, Altmann D, et al.: Microbial translocation is a cause of systemic immune activation in chronic HIV infection. Nat Med 2006, I 2: | 365-7|.

43. Chun TW, Carruth L, Finzi D, Shen X, DiGiuseppe JA, Taylor H, Hermankova M, Chadwick K, Margolick J, Quinn TC, et al.: Quantification of latent tissue reservoirs and total body viral load in HIV-I infection. Nature 1997, 387:183-8.

44. Mattapallil I], Douek DC, Hill B, Nishimura Y, Martin M, Roederer M: Massive infection and loss of memory CD4+ $T$ cells in multiple tissues during acute SIV infection. Nature 2005, 434: 1093-7.

45. Mehandru S, Poles MA, Tenner-Racz K, Manuelli V, Jean-Pierre P, Lopez P, Shet A, Low A, Mohri H, Boden D, et al:: Mechanisms of gastrointestinal CD4+ T-cell depletion during acute and early human immunodeficiency virus type I infection. J Virol 2007, 81:599-612.

46. Rutjens E, Balla-Jhagjhoorsingh S, Verschoor E, Bogers W, Koopman $G$, Heeney J: Lentivirus infections and mechanisms of disease resistance in chimpanzees. Front Biosci 2003, 8: $\mathrm{dI}$ I34-45.

47. Boberg A, Brave A, Johansson S, Wahren B, Hinkula J, Rollman E: Murine models for HIV vaccination and challenge. Expert Rev Vaccines 2008, 7: I 17-30.

48. Zarling JM, Ledbetter JA, Sias J, Fultz P, Eichberg J, Gjerset G, Moran PA: HIV-infected humans, but not chimpanzees, have circulating cytotoxic $T$ lymphocytes that lyse uninfected CD4+ cells. J Immunol 1990, I 44:2992-8.

49. Joag SV: Primate models of AIDS. Microbes Infect 2000, 2:223-9.

50. Hu SL: Non-human primate models for AIDS vaccine research. Curr Drug Targets Infect Disord 2005, 5: 193-20I.

5I. Abel K: The rhesus macaque pediatric SIV infection model a valuable tool in understanding infant HIV-I pathogenesis and for designing pediatric HIV-I prevention strategies. Curr HIV Res 2009, 7:2-II.

52. $\mathrm{Li} J$, Lord $\mathrm{Cl}$, Haseltine W, Letvin NL, Sodroski J: Infection of cynomolgus monkeys with a chimeric HIV-I/SIVmac virus that expresses the HIV-I envelope glycoproteins. J Acquir Immune Defic Syndr 1992, 5:639-46.

53. Keele BF, Jones JH, Terio KA, Estes JD, Rudicell RS, Wilson ML, Li Y, Learn GH, Beasley M, Schumacher-Stankey J, Wroblewski E, Mosser A, Raphael J, Kamenya S, Lonsdorf EV, Travis DA, Mlengeya T, Kinsel MJ, Else JG, Silvestri G, Goodall J, Sharp PM, Shaw GM, Pusey AE, Hahn BH: Increased mortality and AIDS-like immunopathology in wild chimpazees infected with SIVcpz. Nature 2009, 460:515-519.

54. Uhl EW, Martin M, Coleman JK, Yamamoto JK: Advances in FIV vaccine technology. Vet Immunol Immunopathol 2008, I 23:65-80.

55. Burkhard MJ, Dean GA: Transmission and immunopathogenesis of FIV in cats as a model for HIV. Curr HIV Res 2003, I: $15-29$

56. Goffinet C, Michel N, Allespach I, Tervo HM, Hermann V, Krausslich HG, Greene WC, Keppler OT: Primary T-cells from human CD4/CCR5-transgenic rats support all early steps of HIV-I replication including integration, but display impaired viral gene expression. Retrovirology 2007, 4:53.

57. Michel N, Goffinet C, Ganter K, Allespach I, Kewalramani VN, Saifud$\operatorname{din}$ M, Littman DR, Greene WC, Goldsmith MA, Keppler OT: Human cyclin TI expression ameliorates a T-cell-specific transcriptional limitation for HIV in transgenic rats, but is not sufficient for a spreading infection of prototypic R5 HIV. I strains ex vivo. Retrovirology 2009, 6:2

58. Tervo HM, Goffinet C, Keppler OT: Mouse T-cells restrict replication of human immunodeficiency virus at the level of integration. Retrovirology 2008, 5:58.

59. Bosma GC, Custer RP, Bosma MJ: A severe combined immunodeficiency mutation in the mouse. Nature 1983, 301:527-30.

60. McCune JM: Development and applications of the SCID-hu mouse model. Semin Immunol 1996, 8: 187-96.

61. McCune JM, Namikawa $R$, Kaneshima $H$, Shultz LD, Lieberman $M$, Weissman IL: The SCID-hu mouse: murine model for the analysis of human hematolymphoid differentiation and function. Science 1988, 241:1632-9.

62. Mosier DE, Gulizia RJ, Baird SM, Wilson DB: Transfer of a functional human immune system to mice with severe combined immunodeficiency. Nature 1988, 335:256-9. 
63. Tary-Lehmann M, Saxon A, Lehmann PV: The human immune system in hu-PBL-SCID mice. Immunol Today 1995, 16:529-33.

64. Christianson SW, Greiner DL, Hesselton RA, Leif JH, Wagar EJ, Schweitzer IB, Rajan TV, Gott B, Roopenian DC, Shultz LD: Enhanced human CD4+ $T$ cell engraftment in beta2-microglobulindeficient NOD-scid mice. J Immunol 1997, 158:3578-86.

65. Greiner DL, Shultz LD, Yates J, Appel MC, Perdrizet G, Hesselton RM, Schweitzer I, Beamer WG, Shultz KL, Pelsue SC, et al.: Improved engraftment of human spleen cells in NOD/LtSzscid/scid mice as compared with C. Am J Pathol 1995, I 46:888-902.

66. Hesselton RM, Greiner DL, Mordes JP, Rajan TV, Sullivan JL, Shultz LD: High levels of human peripheral blood mononuclear cell engraftment and enhanced susceptibility to human immunodeficiency virus type I infection in NOD/LtSz-scid/scid mice. J Infect Dis 1995, I 72:974-82.

67. Shultz LD, Schweitzer PA, Christianson SW, Gott B, Schweitzer IB, Tennent B, McKenna S, Mobraaten L, Rajan TV, Greiner DL, et al.: Multiple defects in innate and adaptive immunologic function in NOD/LtSz-scid mice. J Immunol 1995, I54:|80-9|

68. Ito M, Kobayashi K, Nakahata T: NOD/Shi-scid IL2rgamma(null) (NOG) mice more appropriate for humanized mouse models. Curr Top Microbiol Immunol 2008, 324:53-76.

69. Pearson T, Greiner DL, Shultz LD: Humanized SCID mouse models for biomedical research. Curr Top Microbiol Immunol 2008, 324:25-5I.

70. Ishikawa F, Yasukawa M, Lyons B, Yoshida S, Miyamoto T, Yoshimoto G, Watanabe T, Akashi K, Shultz LD, Harada M: Development of functional human blood and immune systems in NOD/SCID/ IL2 receptor \{gamma\} chain(null) mice. Blood 2005, 106: 1565-73.

71. Ito M, Hiramatsu H, Kobayashi K, Suzue K, Kawahata M, Hioki K, Ueyama $Y$, Koyanagi $Y$, Sugamura K, Tsuji K, et al.: NOD/SCID/ gamma(c)(null) mouse: an excellent recipient mouse model for engraftment of human cells. Blood 2002, 100:3175-82.

72. Shultz LD, Lyons BL, Burzenski LM, Gott B, Chen X, Chaleff S, Kotb M, Gillies SD, King M, Mangada J, et al:: Human lymphoid and myeloid cell development in NOD/LtSz-scid IL2R gamma null mice engrafted with mobilized human hemopoietic stem cells. J Immunol 2005, 174:6477-89.

73. Traggiai E, Chicha L, Mazzucchelli L, Bronz L, Piffaretti JC, Lanzavecchia A, Manz MG: Development of a human adaptive immune system in cord blood cell-transplanted mice. Science 2004, 304:104-7.

74. Uittenbogaart $\mathrm{CH}$, Anisman DJ, Tary-Lehmann M, Vollger LW, Breit TM, Van Dongen JJ, Saxon A: The SCID mouse environment causes immunophenotypic changes in human immature $T$ cell lines. Int / Cancer 1994, 56:546-5I.

75. Sundell IB, Koka PS: Chimeric SCID-hu Model as a Human Hematopoietic Stem Cell Host That Recapitulates the Effects of HIV-I on Bone Marrow Progenitors in Infected Patients. J Stem Cells 2006, I:283-300.

76. Shultz LD, Ishikawa F, Greiner DL: Humanized mice in translational biomedical research. Nat Rev Immunol 2007, 7: I 18-30.

77. Koyanagi $Y$, Tanaka $Y$, Ito M, Yamamoto N: Humanized mice for human retrovirus infection. Curr Top Microbiol Immunol 2008 324: $133-48$.

78. Denton PW, Garcia JV: Novel humanized murine models for HIV research. Curr HIVIAIDS Rep 2009, 6: 13-9.

79. Koka PS, Fraser JK, Bryson Y, Bristol GC, Aldrovandi GM, Daar ES, Zack JA: Human immunodeficiency virus inhibits multilineage hematopoiesis in vivo. J Virol 1998, 72:5। 2 I-7.

80. Koka PS, Jamieson BD, Brooks DG, Zack JA: Human immunodeficiency virus type I-induced hematopoietic inhibition is independent of productive infection of progenitor cells in vivo. $J$ Virol 1999, 73:9089-97.

81. Goldstein H, Pettoello-Mantovani M, Katopodis NF, Kim A, Yurasov S, Kollmann TR: SCID-hu mice: a model for studying disseminated HIV infection. Semin Immunol 1996, 8:223-3I.

82. Stoddart CA, Bales CA, Bare JC, Chkhenkeli G, Galkina SA, Kinkade AN, Moreno ME, Rivera JM, Ronquillo RE, Sloan B, et al.: Validation of the SCID-hu Thy/Liv mouse model with four classes of licensed antiretrovirals. PLoS One 2007, 2:e655

83. Stoddart CA, Nault G, Galkina SA, Thibaudeau K, Bakis P, BousquetGagnon N, Robitaille M, Bellomo M, Paradis V, Liscourt P, et al.: Albumin-conjugated C34 peptide HIV-I fusion inhibitor: equipo- tent to C34 and T-20 in vitro with sustained activity in SCIDhu Thy/Liv mice. J Biol Chem 2008, 283:34045-52.

84. Stoddart CA, Joshi P, Sloan B, Bare JC, Smith PC, Allaway GP, Wild CT, Martin DE: Potent activity of the HIV-I maturation inhibitor bevirimat in SCID-hu Thy/Liv mice. PLoS One 2007, 2:el25I.

85. Namikawa R, Kaneshima H, Lieberman M, Weissman IL, McCune JM: Infection of the SCID-hu mouse by HIV-I. Science 1988, 242:1684-6

86. Stanley SK, McCune JM, Kaneshima H, Justement JS, Sullivan M, Boone E, Baseler M, Adelsberger J, Bonyhadi M, Orenstein J, et al:: Human immunodeficiency virus infection of the human thymus and disruption of the thymic microenvironment in the SCID-hu mouse. J Exp Med 1993, 178: II5I-63.

87. Aldrovandi GM, Feuer G, Gao L, Jamieson B, Kristeva M, Chen IS, Zack JA: The SCID-hu mouse as a model for HIV-I infection. Nature 1993, 363:732-6.

88. Bonyhadi ML, Rabin L, Salimi S, Brown DA, Kosek J, McCune JM, Kaneshima $\mathrm{H}$ : HIV induces thymus depletion in vivo. Nature 1993, 363:728-32.

89. Miles SA, Mitsuyasu RT, Moreno J, Baldwin G, Alton NK, Souza L, Glaspy JA: Combined therapy with recombinant granulocyte colony-stimulating factor and erythropoietin decreases hematologic toxicity from zidovudine. Blood 1991, 77:2109-17.

90. Withers-Ward ES, Amado RG, Koka PS, Jamieson BD, Kaplan AH, Chen IS, Zack JA: Transient renewal of thymopoiesis in HIVinfected human thymic implants following antiviral therapy. Nat Med 1997, 3: I 102-9.

91. Isgro A, De Vita L, Mezzaroma I, Aiuti A, Aiuti F: Recovery of haematopoietic abnormalities in HIV-I infected patients treated with HAART. Aids 1999, 13:2486-8.

92. McCune JM, Namikawa R, Shih CC, Rabin L, Kaneshima H: Pseudotypes in HIV-infected mice. Science 1990, 250: I I52-4.

93. Kaneshima H Shih CC Namikawa R, Rabin L, Outzen $\mathrm{H}$, Machado SG, McCune JM: Human immunodeficiency virus infection of human lymph nodes in the SCID-hu mouse. Proc Natl Acad Sci USA 199I, 88:4523-7.

94. Greiner DL, Hesselton RA, Shultz LD: SCID mouse models of human stem cell engraftment. Stem Cells 1998, 16:166-77.

95. Nonoyama S, Smith FO, Bernstein ID, Ochs HD: Strain-dependent leakiness of mice with severe combined immune deficiency. J Immunol 1993, 150:38I7-24.

96. Kollmann TR, Pettoello-Mantovani M, Zhuang X, Kim A, Hachamovitch M, Smarnworawong P, Rubinstein A, Goldstein H: Disseminated human immunodeficiency virus I (HIV-I) infection in SCID-hu mice after peripheral inoculation with HIV-I. J Exp Med 1994, I79:513-22

97. Di Fabio S, Giannini G, Lapenta C, Spada M, Binelli A, Germinario E, Sestili P, Belardelli F, Proietti E, Vella S: Vaginal transmission of HIV-I in hu-SCID mice: a new model for the evaluation of vaginal microbicides. Aids 200I, 15:223I-8.

98. Di Fabio S, Van Roey J, Giannini G, Mooter G van den, Spada M, Binelli A, Pirillo MF, Germinario E, Belardelli F, de Bethune MP, et al.: Inhibition of vaginal transmission of HIV-I in hu-SCID mice by the non-nucleoside reverse transcriptase inhibitor TMCI20 in a gel formulation. Aids 2003, 17:1597-604.

99. Santini SM, Rizza P, Logozzi MA, Sestili P, Gherardi G, Lande R, Lapenta $C$, Belardelli $F$, Fais $S$ : The SCID mouse reaction to human peripheral blood mononuclear leukocyte engraftment. Transplantation 1995, 60:1306-14.

100. Tary-Lehmann M, Saxon A: Human mature $T$ cells that are anergic in vivo prevail in SCID mice reconstituted with human peripheral blood. J Exp Med 1992, 175:503-16.

10I. Hoffmann-Fezer G, Gall C, Zengerle U, Kranz B, Thierfelder S: Immunohistology and immunocytology of human T-cell chimerism and graft-versus-host disease in SCID mice. Blood 1993, 81:3440-8.

102. Reinhardt B, Torbett BE, Gulizia RJ, Reinhardt PP, Spector SA, Mosier $D E$ : Human immunodeficiency virus type $I$ infection of neonatal severe combined immunodeficient mice xenografted with human cord blood cells. AIDS Res Hum Retroviruses 1994 , 10:13|-4|.

103. Kawano Y, Tanaka Y, Misawa N, Tanaka R, Kira II, Kimura T, Fukushi M, Sano K, Goto T, Nakai M, et al.: Mutational analysis of human immunodeficiency virus type I (HIV-I) accessory genes: requirement of a site in the nef gene for HIV-I replication in 
activated CD4+ $\mathbf{T}$ cells in vitro and in vivo. I Virol 1997 , 7I:8456-66.

104. Koup RA, Safrit JT, Weir R, Gauduin MC: Defining antibody protection against HIV-I transmission in Hu-PBL-SCID mice. Semin Immunol 1996, 8:263-8.

105. Picchio GR, Valdez H, Sabbe R, Landay AL, Kuritzkes DR, Lederman MM, Mosier DE: Altered viral fitness of HIV-I following failure of protease inhibitor-based therapy. J Acquir Immune Defic Syndr 2000, 25:289-95.

106. Poignard P, Sabbe R, Picchio GR, Wang M, Gulizia RJ, Katinger H, Parren PW, Mosier DE, Burton DR: Neutralizing antibodies have limited effects on the control of established HIV-I infection in vivo. Immunity 1999, 10:431-8.

107. Andrus L, Prince AM, Bernal I, McCormack P, Lee DH, Gorny MK, Zolla-Pazner S: Passive immunization with a human immunodeficiency virus type I-neutralizing monoclonal antibody in Hu-PBL-SCID mice: isolation of a neutralization escape variant. J Infect Dis 1998, 177:889-97.

108. Okamoto Y, Eda Y, Ogura A, Shibata S, Amagai T, Katsura Y, Asano T, Kimachi K, Makizumi K, Honda M: In SCID-hu mice, passive transfer of a humanized antibody prevents infection and atrophic change of medulla in human thymic implant due to intravenous inoculation of primary HIV-I isolate. I Immunol 1998, 160:69-76.

109. Yoshida A, Tanaka R, Murakami T, Takahashi Y, Koyanagi Y, Nakamura $\mathrm{M}$, Ito $\mathrm{M}$, Yamamoto $\mathrm{N}$, Tanaka $\mathrm{Y}$ : Induction of protective immune responses against $\mathrm{R5}$ human immunodeficiency virus type I (HIV-I) infection in hu-PBL-SCID mice by intrasplenic immunization with HIV-I-pulsed dendritic cells: possible involvement of a novel factor of human CD4(+) T-cell origin. J Virol 2003, 77:87| 9-28.

1 10. Yoshida A, Tanaka R, Kodama A, Yamamoto N, Ansari AA, Tanaka Y: Identification of HIV-I epitopes that induce the synthesis of a R5 HIV-I suppression factor by human CD4+ T cells isolated from HIV-I immunized hu-PBL SCID mice. Clin Dev Immunol 2005, I 2:235-42.

III. Prochazka M, Gaskins HR, Shultz LD, Leiter EH: The nonobese diabetic scid mouse: model for spontaneous thymomagenesis associated with immunodeficiency. Proc Natl Acad Sci USA 1992, 89:3290-4.

112. Ogasawara K, Hamerman JA, Hsin H, Chikuma S, Bour-Jordan H, Chen T, Pertel T, Carnaud C, Bluestone JA, Lanier LL: Impairment of NK cell function by NKG2D modulation in NOD mice. Immunity 2003, I 8:4I-5I.

113. Baxter AG, Cooke A: Complement lytic activity has no role in the pathogenesis of autoimmune diabetes in NOD mice. Diabetes 1993, 42:1574-8.

1 14. Lowry PA, Shultz LD, Greiner DL, Hesselton RM, Kittler EL, Tiarks CY, Rao SS, Reilly J, Leif JH, Ramshaw H, et al.: Improved engraftment of human cord blood stem cells in NOD/LtSz-scid/scid mice after irradiation or multiple-day injections into unirradiated recipients. Biol Blood Marrow Transplant 1996, 2:15-23.

1 15. Pflumio F, Izac B, Katz A, Shultz LD, Vainchenker W, Coulombel L: Phenotype and function of human hematopoietic cells engrafting immune-deficient CB I 7-severe combined immunodeficiency mice and nonobese diabetic-severe combined immunodeficiency mice after transplantation of human cord blood mononuclear cells. Blood 1996, 88:373 I-40.

I16. Legrand N, Weijer K, Spits H: Experimental models to study development and function of the human immune system in vivo. J Immunol 2006, 176:2053-8.

I 17. Koyanagi Y, Tanaka Y, Kira J, Ito M, Hioki K, Misawa N, Kawano Y, Yamasaki K, Tanaka R, Suzuki Y, et al.: Primary human immunodeficiency virus type I viremia and central nervous system invasion in a novel hu-PBL-immunodeficient mouse strain. J Virol 1997, $71: 2417-24$.

1 18. Wege AK, Melkus MW, Denton PW, Estes JD, Garcia JV: Functional and phenotypic characterization of the humanized BLT mouse model. Curr Top Microbiol Immunol 2008, 324: I49-65.

119. Denton PW, Estes JD, Sun Z, Othieno FA, Wei BL, Wege AK, Powell DA, Payne D, Haase AT, Garcia JV: Antiretroviral pre-exposure prophylaxis prevents vaginal transmission of HIV-I in humanized BLT mice. PLoS Med 2008, 5: 16.

120. Watanabe S, Terashima K, Ohta S, Horibata S, Yajima M, Shiozawa Y, Dewan MZ, Yu Z, Ito M, Morio T, et al.: Hematopoietic stem cellengrafted NOD/SCID/IL2Rgamma null mice develop human lymphoid systems and induce long-lasting HIV-I infection with specific humoral immune responses. Blood 2007, 109:212-8.

I2I. Watanabe S, Ohta S, Yajima M, Terashima K, Ito M, Mugishima H, Fujiwara S, Shimizu K, Honda M, Shimizu N, et al.: Humanized NOD/ SCID/IL2Rgamma(null) mice transplanted with hematopoietic stem cells under nonmyeloablative conditions show prolonged life spans and allow detailed analysis of human immunodeficiency virus type I pathogenesis. J Virol 2007, 8I:13259-64

122. Goldman JP, Blundell MP, Lopes L, Kinnon C, Di Santo JP, Thrasher $A$ ): Enhanced human cell engraftment in mice deficient in RAG2 and the common cytokine receptor gamma chain. $\mathrm{Br}$ J Haematol 1998, 103:335-42.

123. Mazurier F, Fontanellas A, Salesse $S$, Taine L, Landriau S, MoreauGaudry F, Reiffers J, Peault B, Di Santo JP, de Verneuil H: A novel immunodeficient mouse model - RAG $2 \times$ common cytokine receptor gamma chain double mutants - requiring exogenous cytokine administration for human hematopoietic stem cell engraftment. J Interferon Cytokine Res 1999, 19:533-4I.

124. Gimeno R, Weijer K, Voordouw A, Uittenbogaart CH, Legrand N, Alves NL, Wijnands E, Blom B, Spits H: Monitoring the effect of gene silencing by RNA interference in human CD34+ cells injected into newborn RAG2-/- gammac-/- mice: functional inactivation of p53 in developing $\mathbf{T}$ cells. Blood 2004, 104:3886-93.

125. Baenziger S, Tussiwand R, Schlaepfer E, Mazzucchelli L, Heikenwalder M, Kurrer MO, Behnke S, Frey J, Oxenius A, Joller H, et al.: Disseminated and sustained HIV infection in CD34+ cord blood celltransplanted Rag2-/-gamma c-/- mice. Proc Natl Acad Sci USA 2006, 103:15951-6.

126. Berges BK, Wheat WH, Palmer BE, Connick E, Akkina R: HIV-I infection and CD4 $\mathrm{T}$ cell depletion in the humanized Rag2-Igamma c-/- (RAG-hu) mouse model. Retrovirology 2006, 3:76.

127. Zhang L, Kovalev GI, Su L: HIV-I infection and pathogenesis in a novel humanized mouse model. Blood 2007, 109:2978-8I.

128. Jiang Q, Zhang L, Wang R, Jeffrey J, Washburn ML, Brouwer D, Barbour S, Kovalev GI, Unutmaz D, Su L: FoxP3+CD4+ regulatory T cells play an important role in acute HIV-I infection in humanized Rag2-/-gammaC-/- mice in vivo. Blood 2008, I I 2:2858-68.

129. Gorantla S, Sneller H, Walters L, Sharp JG, Pirruccello SJ, West JT, Wood C, Dewhurst S, Gendelman HE, Poluektova L: Human immunodeficiency virus type I pathobiology studied in humanized BALB/c-Rag2-/-gammac-/- mice. | Virol 2007, $81: 2700-12$

130. An DS, Poon B, Ho Tsong Fang R, Weijer K, Blom B, Spits H, Chen IS, Uittenbogaart $\mathrm{CH}$ : Use of a novel chimeric mouse model with a functionally active human immune system to study human immunodeficiency virus type I infection. Clin Vaccine Immunol 2007, | 4:39|-6.

13I. Van Duyne R, Cardenas J, Easley R, Wu W, Kehn-Hall K, Klase Z, Mendez S, Zeng C, Chen H, Saifuddin M, et al.: Effect of transcription peptide inhibitors on HIV-I replication. Virology 2008, 376:308-22

132. ter Brake O, Legrand N, von Eije KJ, Centlivre M, Spits H, Weijer K, Blom B, Berkhout B: Evaluation of safety and efficacy of RNA against HIV-I in the human immune system (Rag-2(-/-)gammac(-/-) mouse model. Gene Ther 2009, 16: | 48-53.

133. Berges BK, Akkina SR, Folkvord JM, Connick E, Akkina R: Mucosal transmission of $R 5$ and $X 4$ tropic HIV-I via vaginal and rectal routes in humanized Rag2-/- gammac -/- (RAG-hu) mice. Virology 2008, 373:342-5I.

134. Hofer U, Baenziger S, Heikenwalder M, Schlaepfer E, Gehre N, Regenass S, Brunner T, Speck RF: RAG2-/- gamma(c)-/- mice transplanted with CD34+ cells from human cord blood show low levels of intestinal engraftment and are resistant to rectal transmission of human immunodeficiency virus. J Virol 2008, 82:12145-53.

135. Verdonck K, Gonzalez E, Van Dooren S, Vandamme AM, Vanham G, Gotuzzo E: Human T-lymphotropic virus I: recent knowledge about an ancient infection. Lancet Infect Dis 2007, 7:266-8I.

136. Yasunaga J, Matsuoka M: Human T-cell leukemia virus type I induces adult T-cell leukemia: from clinical aspects to molecular mechanisms. Cancer Control 2007, 14:133-40. 
137. Takatsuki K: Discovery of adult T-cell leukemia. Retrovirology 2005, 2:16.

138. Yoshida M, Satou Y, Yasunaga J, Fujisawa J, Matsuoka M: Transcriptional control of spliced and unspliced human T-cell leukemia virus type I bZIP factor (HBZ) gene. J Virol 2008, 82:9359-68.

139. Kashanchi F, Brady JN: Transcriptional and post-transcriptional gene regulation of HTLV-I. Oncogene 2005, 24:5938-5I.

140. Faris M: Potential for molecular targeted therapy for adult Tcell leukemia/lymphoma. Int Rev Immunol 2008, 27:7I-8.

141. Murata K, Yamada Y: The state of the art in the pathogenesis of ATL and new potential targets associated with HTLV-I and ATL. Int Rev Immunol 2007, 26:249-68.

142. Usui T, Yanagihara K, Tsukasaki K, Murata K, Hasegawa H, Yamada $Y$, Kamihira S: Characteristic expression of HTLV-I basic zipper factor (HBZ) transcripts in HTLV-I provirus-positive cells. Retrovirology 2008, 5:34.

143. Saito M, Matsuzaki T, Satou Y, Yasunaga J, Saito K, Arimura K, Matsuoka $M$, Ohara $Y$ : In vivo expression of the $H B Z$ gene of HTLV-I correlates with proviral load, inflammatory markers and disease severity in HTLV-I associated myelopathyl tropical spastic paraparesis (HAM/TSP). Retrovirology 2009, 6:19.

144. Shimoyama M: Diagnostic criteria and classification of clinical subtypes of adult T-cell leukaemia-lymphoma. $\mathrm{Br} J$ Haematol 199|, 79: 1984-87.

145. Feuer G, Fraser JK, Zack JA, Lee F, Feuer R, Chen IS: Human T-cell leukemia virus infection of human hematopoietic progenitor cells: maintenance of virus infection during differentiation in vitro and in vivo. J Virol 1996, 70:4038-44.

146. Nadella MV, Shu ST, Dirksen WP, Thudi NK, Nadella KS, Fernandez SA, Lairmore MD, Green PL, Rosol TJ: Expression of parathyroid hormone-related protein during immortalization of human peripheral blood mononuclear cells by HTLV-I: implications for transformation. Retrovirology 2008, 5:46.

147. Matsuoka M, Jeang KT: Human T-cell leukaemia virus type I (HTLV-I) infectivity and cellular transformation. Nat Rev Cancer 2007, 7:270-80.

148. Peloponese JM Jr, Kinjo T, Jeang KT: Human T-cell leukemia virus type I Tax and cellular transformation. Int J Hematol 2007, 86: $101-6$.

149. Agbottah E, Yeh WI, Berro R, Klase Z, Pedati C, Kehn-Hall K, Wu W, Kashanchi F: Two specific drugs, BMS-34554I and purvalanol A induce apoptosis of HTLV-I infected cells through inhibition of the NF-kappaB and cell cycle pathways. AIDS Res Ther 2008, 5:12

150. Feuer G, Zack JA, Harrington WJ Jr, Valderama R, Rosenblatt JD, Wachsman W, Baird SM, Chen IS: Establishment of human T-cell leukemia virus type I T-cell lymphomas in severe combined immunodeficient mice. Blood 1993, 82:722-31.

15I. Kondo A, Imada K, Hattori T, Yamabe H, Tanaka T, Miyasaka M, Okuma $M$, Uchiyama $T$ : A model of in vivo cell proliferation of adult T-cell leukemia. Blood 1993, 82:250I-9.

152. Liu Y, Dole K, Stanley JR, Richard V, Rosol TJ, Ratner L, Lairmore M, Feuer G: Engraftment and tumorigenesis of HTLV-I transformed T cell lines in SCID/bg and NOD/SCID mice. Leuk Res 2002, 26:56I-7.

153. Tanaka M, Sun B, Fang J, Nitta T, Yoshida T, Kohtoh S, Kikukawa H, Hanai S, Uchida K, Miwa M: Human T-cell leukemia virus type I (HTLV-I) infection of mice: proliferation of cell clones with integrated HTLV-I provirus in lymphoid organs. J Virol 200I, 75:4420-3.

154. Miyazato $P$, Yasunaga J, Taniguchi $Y$, Koyanagi $Y$, Mitsuya H, Matsuoka $M$ : De novo human T-cell leukemia virus type I infection of human lymphocytes in NOD-SCID, common gamma-chain knockout mice. J Virol 2006, 80: 10683-9|.

155. Takajo I, Umeki K, Morishita K, Yamamoto I, Kubuki Y, Hatakeyama K, Kataoka H, Okayama A: Engraftment of peripheral blood mononuclear cells from human T-lymphotropic virus type I carriers in NOD/SCID/gammac(null) (NOG) mice. Int J Cancer 2007, I $21: 2205-11$.

156. Ohsugi T, Kumasaka T, Ishida A, Ishida T, Horie R, Watanabe T, Umezawa $\mathrm{K}$, Yamaguchi $\mathrm{K}$ : In vitro and in vivo antitumor activity of the NF-kappaB inhibitor DHMEQ in the human T-cell leukemia virus type I-infected cell line, HUT-102. Leuk Res 2006, 30:90-7.
157. Ohsugi T, Kumasaka T, Okada S, Ishida T, Yamaguchi K, Horie R, Watanabe T, Umezawa K: Dehydroxymethylepoxyquinomicin (DHMEQ) therapy reduces tumor formation in mice inoculated with tax-deficient adult T-cell leukemia-derived cell lines. Cancer Lett 2007, 257:206-15.

158. Shu ST, Nadella MV, Dirksen WP, Fernandez SA, Thudi NK, Werbeck J, Lairmore MD, Rosol TJ: A novel bioluminescent mouse model and effective therapy for adult T-cell leukemia/lymphoma. Cancer Res 2007, 67: I 1859-66.

159. Nitta T, Tanaka M, Sun B, Sugihara E, Kimura M, Kamada Y, Takahashi $\mathrm{H}$, Hanai S, Jiang SW, Fujisawa J, et al.: Reduction of human T-cell leukemia virus type-I infection in mice lacking nuclear factor-kappaB-inducing kinase. Cancer Sci 2008, 99:872-8.

160. Chen J, Zhang M, Ju W, Waldmann TA: Effective treatment of a murine model of adult T-cell leukemia using depsipeptide and its combination with unmodified daclizumab directed toward CD25. Blood 2009, I I 3: 1287-93.

161. Dittmer D, Stoddart C, Renne R, Linquist-Stepps V, Moreno ME, Bare C, McCune JM, Ganem D: Experimental transmission of Kaposi's sarcoma-associated herpesvirus (KSHV/HHV-8) to SCID-hu Thy/Liv mice. J Exp Med 1999, 190: 1857-68.

162. Gobbi A, Stoddart CA, Locatelli G, Santoro F, Bare C, Linquist-Stepps V. Moreno ME, Abbey NW, Herndier BG, Malnati MS, et al: Coinfection of SCID-hu Thy/Liv mice with human herpesvirus $\mathbf{6}$ and human immunodeficiency virus type I. J Virol 2000, 74:8726-3I.

163. Alfonzo M, Blanc D, Troadec C, Huerre M, Eliaszewicz M, Gonzalez G, Koyanagi $Y$, Scott-Algara D: Temporary restoration of immune response against Toxoplasma gondii in HIV. infected individuals after HAART, as studied in the huPBMC-SCID mouse model. Clin Exp Immunol 2002, I 29:4I I-9.

Publish with Bio Med Central and every scientist can read your work free of charge

"BioMed Central will be the most significant development for disseminating the results of biomedical research in our lifetime. "

Sir Paul Nurse, Cancer Research UK

Your research papers will be:

- available free of charge to the entire biomedical community

- peer reviewed and published immediately upon acceptance

- cited in PubMed and archived on PubMed Central

- yours - you keep the copyright 